\title{
La iconografía en la era digital: hacia una heurística para el estudio del contenido de las imágenes medievales
}

\author{
Begoña Cayuela \\ Grup de Recerca Ars Picta, Universitat de Barcelona \\ begonya.cayuela@gmail.com \\ http://orcid.org/OOOO-OOOI-9798-0946 \\ Rebut o6/o6/20I4; acceptat 2I/o7/20I4 \\ DOI Io.7203/MCLM.I.3796
}

\section{The iconography in the digital era: towards a heuristic for studying the content of medieval images}

\begin{abstract}
This article invites us to consider the usefulness of iconography as a method to describe the subjects represented in medieval works of art. In this study, a greater emphasis has been put on investigating the epistemological implications resulting from the use of that method, and the biases that may appear in the process of transforming images into words. The aim is to address what has been called the "semantic gap", i.e., a kind of barrier that prevents the verbal representation of a non-lexical medium, such as the visual one, in a satisfactory and undiminished way. After a brief panorama of image theory throughout the classical era, with especial reference to the rhetorical genre of ekphrasis, this study suggests that, beneath the apparent balance between the verbal and the visual media, a rivalry persists. Later on, in medieval times, a mutation occurs in the way we perceive the visual arts and the images start being considered as texts that can be read. Thanks to the prejudice implied by the statement that we can only attain knowledge through words, the image is relegated to a decorative role or, at the most, an instrument of evangelisation of the illiterate.

In the discipline of medieval art history, defective uses of iconography have led to question its validity as a tool for analysis, even after the systematizing task endeavoured by Erwin Panofsky. Iconography, however, has gained new momentum thanks largely to the creation of digital collections that require iconographic principles to facilitate the recovery of visual documents. The new technologies, however, have accentuated the semantic gap between image and word, and nuanced the value of iconography, combined with indexing techniques based on controlled vocabularies and thesauri. In addition, a critical survey has been made of the most interesting projects which have undertaken the task of indexing the medieval art. Finally, it is argued that migration of iconography into the Web can be the hard core that allows medieval art history to step forward and fully enter into the domain of digital humanities.
\end{abstract}

KEYWORDS

Iconography; Medieval Art; Middle Ages; image-text relationship; ekphrasis; digital collections; iconographic indexing; thesauri.

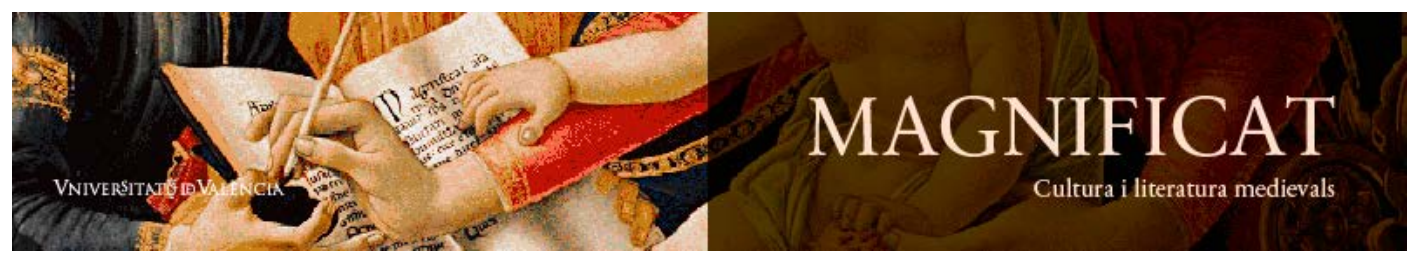

Magnificat Cultura i Literatura Medievals I, 20I4, I-36.

http://ojs.uv.es/index.php/MCLM

ISSN $2386-8295$ 


\section{RESUMEN}

Este artículo invita a reflexionar sobre la validez de la iconografía como método para describir los temas representados en las obras artísticas medievales. En esta ocasión, se ha puesto un mayor énfasis en investigar sus implicaciones epistemológicas y los sesgos que resultan del proceso de transformar las imágenes en palabras. El objetivo principal es tratar de que aflore la llamada "brecha semántica”, una especie de barrera que impide representar verbalmente un medio no léxico, como es el visual, de manera satisfactoria y sin mermas. Tras un sucinto recorrido por el pensamiento griego, con un especial interés por la écfrasis, se sugiere que el aparente equilibrio entre las capacidades semánticas del medio visual y el verbal esconde una rivalidad entre la palabra y la imagen. Más tarde, en época medieval, se opera una mutación en la manera de percibir las artes visuales y las imágenes se convierten en textos que se pueden leer. Durante la Edad Media toma cuerpo un prejuicio por el cual solo la palabra expresa conocimiento mientras que la imagen queda relegada a un papel decorativo o, como mucho, a un instrumento de evangelización de los iletrados.

En el campo de la historia del arte medieval, los desajustes que afloran al usar palabras para describir las obras de arte visuales han provocado cierto escepticismo hacia la iconografía como una herramienta de análisis adecuada, aun cuando Erwin Panofsky contribuyó a la sistematización del método. Con todo, la iconografía ha cobrado un impulso renovado gracias a la creación de repositorios digitales que requieren de la indexación iconográfica para garantizar una recuperación eficiente de las imágenes catalogadas. Sin embargo, las nuevas tecnologías han exacerbado la brecha semántica entre la imagen y la palabra, al tiempo que han matizado el valor de métodos tradicionales como la iconografía, conjugada con técnicas de indexación basadas en vocabularios controlados y tesauros. En este sentido, se ha hecho un repaso crítico de las experiencias más interesantes en la indexación del arte medieval. En definitiva, la migración de la iconografía a la Web puede constituir parte del núcleo duro que permita a la historia de arte medieval dar un paso al frente y entrar de pleno en el dominio de las humanidades digitales.

\section{Palabras clave}

Iconografía; arte medieval; Edad Media; relación imagen-texto; écfrasis; colecciones digitales; indexación iconográfica; tesauros.

Begoña Cayuela, 20I4, "La iconografía en la era digital: hacia una heurística para el estudio del contenido de las imágenes medievales”, Magnificat Cultura i Literatura Medievals I, I-36.

\section{TABLA DE CONTENIDOS}

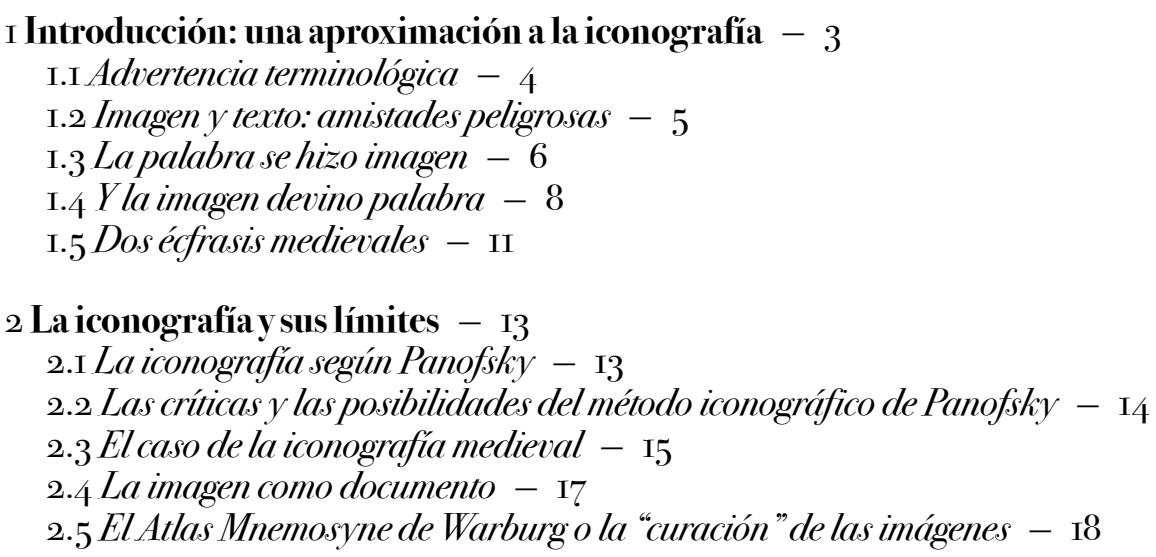

3 El salto de la iconografía al mundo digital - I9

3.I Los catálogos iconográficos en la práctica digital - 20

3.2 Indexar el Arte Medieval - 2I

3.2.I Antecedentes ilustres en la indexación iconográfica de imágenes medievales - 22

$3 \cdot 3$ Tendiendo puentes para sortear la brecha semántica - 23

3.3.I Las posibilidades del reconocimiento automático del contenido de las imágenes - 24

3.4 Los principios de la indexación iconográfica -25

3.4.I De taxonomías y tesauros: casos prácticos -26

${ }_{4}$ Conclusiones -29

5 Obras citadas -30 


\section{ə*⿻}

"Je ne peins pas ce que je vois, je peins ce que je pense"

Pablo Picasso

\section{Introducción: una aproximación a la iconografía}

L ua iconografía describe, analiza y, eventualmente, interpreta el contenido de las imágenes generadas por las artes visuales mediante el lenguaje verbal. El método, así definido, podría considerarse neutro y carente de una base teórica sofisticada. Sin embargo, dado que la iconografía representa las imágenes con palabras, su aplicación trasciende el plano heurístico al poner en contacto dos registros semánticos diferentes, el visual y el verbal. En realidad, se trata de un método con una notable carga epistemológica, como veremos más adelante, puesto que el análisis iconográfico induce a la reflexión sobre la capacidad gnoseológica de las imágenes creadas por el hombre. Es decir, de un lado se consideran las posibilidades comunicativas que tienen las imágenes para transmitir información de manera independiente a la palabra, y de otro, si esta información visual se puede capturar sin mermas y traducirse al lenguaje verbal. Tales implicaciones epistemológicas han condicionado no solo la percepción que tenemos sobre las imágenes, sino también la construcción de las metodologías que se han elaborado para su análisis. Unas metodologías que, en todos los casos, están basadas siempre en el lenguaje verbal, un medio diferente al de las imágenes.

Las concepciones-y preconcepciones-sobre las obras de arte visuales y sus subrogaciones, las imágenes, han configurado la práctica iconográfica. Tradicionalmente, la actitud hacia las imágenes ha sido ambigua; también la de los propios historiadores del arte. Los criterios aplicados oscilan entre el reconocimiento de su eficacia para transmitir mensajes complejos (una imagen vale más que mil palabras), y una función meramente decorativa cuya utilidad se limita, a lo sumo, a la de ilustración de las palabras, pero que, en definitiva, es incapaz de añadir conocimiento a lo que ya se ha articulado de manera verbal, bien sea oralmente o por escrito. Por consiguiente, la interpretación de los sistemas no verbales implica que los expertos introducen, casi de manera instintiva, unos sesgos cognitivos que afectan a su objeto de estudio, la obra de arte visual.

En el caso concreto de los historiadores del arte medieval, el método iconográfico se ha empleado con solvencia y, normalmente, se complementa con otros recursos de la disciplina, como el análisis estilístico de corte formalista. Entre los objetivos de los estudiosos del arte medieval se pueden reseñar los de restituir cabalmente los procesos de génesis, evolución, difusión, recepción y, eventualmente, extinción, e incluso fosilización, de las formas artísticas y sus modelos, y la iconografía constituye uno de los implementos de trabajo con los que cuentan.

La investigación iconográfica supone el manejo de un gran número de imágenes con el fin de poder realizar comparaciones, establecer relaciones y dibujar líneas de filiación. Los avances de las tecnologías digitales y el desarrollo de Internet han puesto al alcance de los medievalistas una cantidad tan desorbitada de imágenes que simplemente su localización resulta una tarea tan ardua como confusa. En el mundo digital, la gestión de las imágenes es extremadamente compleja, especialmente en lo que se refiere a las búsquedas según su contenido, lo que se denomina

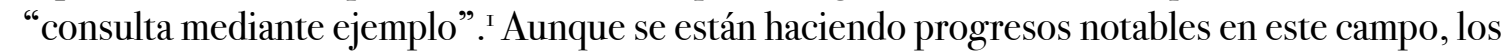

I. Vid. “Consulta de imágenes mediante ejemplo" en Wikipedia.es, http://tinyurl.com/l2wdyt8 (checked oI-O2$2014)$. 
algoritmos automatizados no pueden reconocer todavía los temas representados en las imágenes, y menos, aquellos que interesan a los historiadores del arte medieval. A día de hoy, no es posible recuperar eficientemente todas las imágenes que presenten un determinado asunto a partir de una muestra visual. La única opción que el especialista en arte medieval tiene de recuperar imágenes significativas para su investigación es mediante consultas basadas en descripciones textuales precisas. La relevancia de los resultados de las búsquedas está en función de que dichas imágenes vayan acompañadas de un título significativo o de etiquetas textuales que describan suficientemente el asunto figurado en ellas, porque sin esos atributos la imagen es irrecuperable. En este nuevo contexto digital, en el que se ha ensanchado la brecha entre la imagen y la palabra, la iconografía se ha revelado como un método realmente estratégico para el historiador del arte, el puente que permite conectar ambos registros semánticos.

\section{I.I Advertencia terminológica}

Antes de proseguir, debe hacerse una aclaración terminológica. En este ensayo se preferirá el concepto de "imagen" frente al de "obra de arte" como una opción de compromiso. Los antiguos griegos llamaban techne $(\tau \dot{\varepsilon} \chi \nu \eta)$ a diferentes y variadas actividades productivas humanas, entre ellas, las que fabricaban artefactos con valencia visual. Su equivalente latino era ars y, aunque generalmente se traduce como arte, apenas se corresponde con el sentido que el concepto tiene hoy en día (vid. Tatarkiewicz 2OOI, esp. 39-40 y Io8-I3). Los términos techne y ars denominaban tanto las artes como los oficios y hacían referencia a artefactos realizados con destreza y "de acuerdo con unos principios y reglas establecidas” (Tatarkiewicz 2OOI, IO9); esta es la concepción que perduró durante toda la Edad Media (vid. Galí I999, esp. 47-9I).

Por otra parte, en la disciplina de la historia del arte medieval, el concepto de imagen ha venido a desbancar a los términos tradicionales de obra de arte o de producción artística. Especialistas como Hans Belting afirman que solo se puede hablar de arte a partir del Renacimiento, mientras que la "época anterior habría de llamarse la era de la imagen" (Belting 2009, 5). Contribuciones como las de Belting o las de Jean-Claude Schmitt (2002) han tenido el efecto de resaltar, o si se prefiere, rescatar para la disciplina el concepto de imagen, al tiempo que han activado la reflexión sobre la multiplicidad semántica de su ancestro medieval, el término imago, frente a los sentidos actuales de la palabra. ${ }^{2}$ Además, una historia de las imágenes medievales permite incluir cualquier producción visual, no solo aquellas filtradas por criterios estéticos. Debe recordarse, no obstante, que el término Arte, con mayúsculas y como forma abreviada de Bellas Artes, es un constructo que emerge a partir del Renacimiento, y que ha evolucionado a lo largo del tiempo para adquirir un sentido mucho más restrictivo del que tenía la palabra ars en época antigua o medieval. Es su acepción moderna, una categorización anacrónica, la que ha llevado a los medievalistas a reconsiderar un uso que, paradójicamente, no se daba en la Edad Media, en la que se usaban términos como artifex para

2. Las ideas de Belting se enmarcan en el contexto teórico de la denominada Bildwissenschaft o "Ciencia de las imágenes" (vid. Bredekamp 2003), desarrollada a partir de la última década del s. XX en la Alemania en proceso de reunificación, en un ambiente que coincide con el redescubrimiento de Aby Warburg (I867-I929) (vid. Werckmeister 2006). En otros ámbitos lingüísticos se han elaborado enfoques y reflexiones metodológicos paralelos o, mejor, análogos, puesto que sus fronteras parecen muy difusas, todas ellas con una común desafección por la historia del arte tradicional (vid. Rampley 20I2). Así, en el mundo anglosajón han prosperado los llamados Visual Studies (“Estudios Visuales”), mientras que en el mundo francófono ha tenido un enorme pujanza la perspectiva antropológica (vid. Voyer 2OIO), pero también una reflexión profunda y estimulante sobre la imagen medieval (vid. Schmitt 20O2). En todos estos círculos de debate el término clave es siempre es el de “imagen”, claramente distinto al de arte. 
aludir a los artistas.

Sea cual sea la nomenclatura utilizada, los historiadores del arte medieval se enfrentan a un panorama plagado de lagunas irrecuperables y cuya historia es apenas un trazo difuso, puesto que los imaginarios visuales que conformaban la vida de los hombres y mujeres medievales son escasamente conocidos. Resulta difícil hacerse una idea de la cantidad de imágenes de que constaba la vida de una persona en el siglo VIII, en el X o en el XII desde la perspectiva de la época contemporánea, invadida por la omnipresencia de la imagen, ya sea ésta real o virtual. Al mismo tiempo se ha alertado sobre ciertos abusos que derivan de la falta de perspectiva histórica. En efecto, debe tenerse en cuenta que ni las bibliotecas medievales mejor surtidas podían siquiera aproximarse a una compilación como la Patrologia latina de Migne, ni existía ningún compendio iconográfico parecido al Index of Christian art al alcance de promotores o artesanos (Christe 2006, 288), por no hablar de la inmediatez de los medios digitales que proliferan en la actualidad.

\section{I.2 Imagen y texto: amistades peligrosas}

Tras el largo excursus retomamos el eje argumental de este ensayo: las relaciones entre texto e imagen que resultan del análisis iconográfico. Con el propósito de contextualizar la dinámica de estas interacciones desde el punto de vista de la historia del arte medieval, es necesario realizar un breve recorrido histórico, que hunde sus raíces en la Antigüedad clásica, por la hermenéutica de la percepción visual relacionada con la cuestión iconográfica. Las comparaciones entre texto e imagen esconden un prejuicio muy arraigado, que afecta también a los estudios de historia del arte, por el que la palabra tendría un componente intelectual del que carecería la imagen. En este sentido, la época medieval resulta un laboratorio privilegiado para investigar el valor semántico de las imágenes y los sesgos cognitivos que conlleva su subordinación frente a la palabra. Ello se debe a que durante la Edad Media se consolidó la teoría cristiana de las imágenes, como explicaremos más adelante, cuyo relato incluye numerosos filones para un análisis detallado del tema: pugnas por las imágenes que en ocasiones derivaron en verdaderas luchas iconoclastas, una fractura inabordable entre los que sabían leer y toda una masa analfabeta a la cual se instruía con imágenes, como se repite frecuentemente en la historiografía sobre el tema, etc.

Se podría afirmar, aunque sea una reducción explicativa, que la concepción medieval de la imagen, como producto de las artes visuales, se distanció significativamente de los postulados del mundo grecorromano. Uno de los axiomas principales de la teoría clásica consideraba que, aunque la palabra y las artes visuales utilizan diferentes mecanismos expresivos, estos eran igualmente válidos para representar la realidad; es más, las artes visuales podían llegar a expresar y transmitir un cierto tipo de conocimiento. Esta teoría llegó a convertirse en un topos que se ha formulado de diversas maneras. Deben destacarse el célebre aforismo de Horacio (65-8 a.C.) "ut pictura poesis" (Ars poetica, 36I) y el símil "poema pictura loquens, pictura poema silens" (De gloria Atheniensium, III, 346f-347c, esp. 347a), que Plutarco (45-I20 d.C.) atribuye a Simónides de Keos (556-468 a.C.). En realidad, la teoría clásica nunca postuló la total autonomía expresiva ni de la palabra ni de la imagen, sino que ambas podían representar la realidad utilizando diferentes recursos comunicativos (Lee I982, esp. I3-I9); el poeta y el pintor eran fabricantes de imágenes (Goldhill 2OO7, 5).

Por el contrario, algunos estudiosos opinan que se ha tergiversado el sentido original del símil horaciano; dichos autores sostienen que esta relación aparentemente ponderada entre la palabra y la imagen no es más que eso, un lugar común de la mentalidad antigua (Markiewicz-Gabara 1987). En efecto, en el mundo griego también consta la opinión de la superioridad y precedencia de la palabra con respecto a la imagen. Se puede citar, por ejemplo, a Dión de Prusa (4O-IIo d.C.), quien señalaba en su Discurso olímpico XII(IO5 d.C.) que los pintores no hacían más que emular 
a los poetas como creadores de imágenes (Disc. olímp. XII, 45). Este autor añadía que los artistas interpretan la divinidad con creaciones hechas para ser percibidas por la vista y, por ello, son especialmente aptas para los más ignorantes, un argumento que más tarde revisitaremos de la mano del papa Gregorio Magno (s. VI d.C.). Según Dión, las obras de los artistas complacen y conmueven al espectador mediante el sentido de la vista (ibid., 52), pero su fidelidad a la verdad depende de las aportaciones previas de otras artistas, como los poetas, que vehiculan el pensamiento con la palabra (ibid., 57). Dión de Prusa concluye con el clásico argumento de que no hay pintor o escultor capaz de representar el pensamiento o la razón (ibid., 59).

En cuanto a los más señeros filósofos griegos, cabe mencionar a Platón, cuyas alusiones sobre este tema resultan ambivalentes. Es cierto que señala que un artista solo puede representar lo visible pero no lo inmaterial, como los pensamientos, que solo son accesibles a través de la palabra, el logos (Halliwell 2000, IOZ). Sin embargo, Platón reconoce también que el artista debe hacer un cierto proceso mental para transferir el modelo a su representación visual. En el diálogo Gorgias, incluso llega decir que no se podía separar el arte del conocimiento (Labrada r984, 52). Aunque Platón no desarrolla una doctrina sobre el arte, es posible detectar un interés sostenido por una ética de la forma, cuya principal preocupación radica en que la belleza de las imágenes trasciende las apariencias al encarnar unos valores éticos, es decir, que la forma no solo es un mero reflejo óptico, sino que comunica unos valores (Halliwell 200O, IO7-IO8). ${ }^{3}$

Aristóteles, por su parte, afirma que la techne es una forma de saber (Labrada 1984, 50). En la Ética a Nicómaco, por ejemplo, Aristóteles concede la participación del arte en la racionalidad, aunque no como conocimiento puramente teórico sino de tipo productivo, una poietiké epistéme, que reviste un conocimiento práctico (Tatarkiewicz 200I, Io9; Labrada, I984). Por último, en lo que concierne a este estudio, resulta interesante la comparación que establece entre el argumento poético (de la tragedia) con el tema identificable a través de las formas pictóricas: "una tela manchada al azar con los colores más deliciosos nunca resultaría tan agradable como un retrato hecho de contornos" (Lee I982, I6).

\section{I.3 La palabra se hizo imagen}

La écfrasis (ekphrasis) es uno de los productos discursivos griegos que surgen de las interacciones, o mejor, de las tensiones entre la imagen y la palabra. ${ }^{4}$ Se trata de una descripción que intenta representar vívidamente (enargeia) el asunto que se describe, tanto que posibilite su visualización interior. Nacido en el mundo antiguo griego, este género literario prosperó en el contexto de una rica cultura retórica y, más tarde, se difundió a los territorios latinos del imperio romano. Tanto en Oriente como en Occidente, el cultivo de la écfrasis perduró hasta la Edad Media, aunque fue notoriamente más frecuentada por los autores bizantinos.

En los manuales de retórica se definía la écfrasis como un proceso descriptivo verbal con un efecto transformador visual; lo que no se detallaba era cómo operaría dicha transformación (Squire 20I3, IOO). En realidad, este efecto depende de la capacidad de asombro que origina la

3. Esta idea de mero reflejo por la que se entiende la mimesis, una imitación de la naturaleza, es la versión más conocida de las ideas de Platón sobre el arte, y que se exponen en la República, X, 596d-e. Historiadores del arte tan influyentes como Ernst Gombrich contribuyeron a fijar la idea de que el filósofo griego tenía una opinión negativa sobre el arte que se ha perpetuado en la disciplina (Gombrich 1984, 93; Halliwell 2000, I03; sin embargo vid. una crítica a todas estas cuestiones en Galí I999, 93-I40, 257ss., esp. 274-75, y 296ss).

4. El tema de las ekphraseis ha recibido gran atención en los últimos años gracias, entre otros, a los trabajos de Elsner I995 y 20IO, Goldhill 2007 o Webb 2009. 
“visualización” inducida por la écfrasis. Se trata de una fascinación que produce una especie de ceguera intelectual, pues es capaz de cortocircuitar las facultades críticas del espectador (Goldhill 2007, 5-7). La écfrasis subvierte los campos semánticos de la imagen y la palabra, de modo que esta última se erige en verdadera protagonista del acto visual: ver a través de la palabra.

Gracias a esta capacidad para provocar la visualización, la descripción de las obras de arte se incluyó entre las competencias de la écfrasis; de hecho, se convirtió en su tema exclusivo a partir del s. III d.C. (Lizcano 2000, 63-85). El cultivo de la écfrasis pretendía mostrar que, en la práctica, las descripciones verbales permiten ir más allá de la mera contemplación óptica. Con este objetivo, la fantasía (phantasia) resultaba fundamental, ya que contribuía a rememorar aquello que se describía, como una obra artística, sin que estuviera necesariamente presente, e incluso, sin que existiera realmente; podría decirse que la materialidad física de dicha obra se hacía innecesaria y hasta redundante. Así pues, en el dominio de la écfrasis, la fantasía juega un papel crucial al tratarse de una percepción intuitiva que genera conocimiento a partir de la cosa percibida. Gracias a la fantasía, dice Quintiliano, la audiencia puede ver cosas que están ausentes, es el recurso retórico de evocar y poner ante los ojos lo que se describe: "ut eas cernere oculis ac praesentes habere videamur" (Institutiones, 6.2. 29-30). En resumen, tanto la fantasía como la enargeia, o habilidad para evocar vívidamente, son dos componentes fundamentales de la écfrasis.

De igual modo, en el mundo griego antiguo, la écfrasis permitía ampliar la capacidad verbal para relacionarse con lo invisible, incluso con lo sagrado; no solo eso, sino que competía con las representaciones visuales de los dioses para revelar, mediante la palabra, a la divinidad ante la percepción humana (Platt 2OII). De hecho, la écfrasis terminó por apropiarse del prestigio que tenía el sentido visual en las apariciones epifánicas, puesto que el pensamiento griego daba una mayor importancia a los ojos para acceder a la verdad. ${ }^{5}$ Desde el siglo IV a.C., visión y conocimiento son dos conceptos que están íntimamente ligados porque orbitan sobre el campo semántico del término theōria. Dicen los expertos que la palabra griega theōria significaba originalmente contemplar un espectáculo sagrado, especialmente un ritual, pero, a partir del siglo IV a.C., empezó a denotar una vía de acceso al conocimiento que posibilitaba "ver la verdad" (Nightingale 2004; Platt 2OII, II). ${ }^{6}$ Sin embargo, otros especialistas afirman justo lo contrario y aseguran que, en el mundo griego, los discursos relativos a la visión, entre ellos, la écfrasis, están asociados a una "ideología de la voz" (Squire 20I3, 98).

En definitiva, la écfrasis podía representar la realidad invisible gracias a la phantasia, superando así a la mimesis, que únicamente alcanzaba a imitar lo que pueden ver los ojos. Esta misma capacidad se acordaba para algunas pinturas o esculturas. Por ello, es posible entender por phantasia la visión creativa de la mente del poeta y del artista cuando, a su vez, consiguen excitar la phantasia del espectador para transmitir la verdad (Elsner 1995, 26-27).

Dentro de la producción retórica de la écfrasis nos interesa destacar las Imagines de Filóstrato el Viejo (s. II-III d.C.). ${ }^{7}$ En esta obra se puede rastrear una epistemología de las imágenes visuales,

5. Por el contrario, en el pensamiento griego preplatónico, del siglo VI al V a.C., la adquisición de conocimiento implica al sentido del oído, no al de la vista, para poder recibir los mensajes de un logos divino (Nightingale 20O4, 32$33)$.

6. Se ha conjeturado que el pensamiento griego del siglo IV a.C. se apropia de una institución civil presocrática, la theōria, que consistía en peregrinar a los centros religiosos extranjeros más importantes para contemplar los espectáculos que allí se celebraban. El peregrino enviado por la polis, llamado theoros, debía explicar a su vuelta lo que había visto. Por ello se ha especulado con que la etimología del término teoría procede de Theos (dios) o Thea (mirada, espectáculo), o de ambas palabra a la vez (vid. Nightingale 2004, 40 y siguientes, esp. 45).

7. Si bien aquí se ha optado por Filóstrato, la Dra. Milagros Guardia, catedrática de Arte Medieval en la Universitat de Barcelona, a quien agradezco sus comentarios sobre esta cuestión, me ha recordado especialmente a Luciano de 
pues, según Filóstrato, tanto la pintura como la poesía podían transmitir conocimiento (Imagines, I, 294k). ${ }^{8}$ La écfrasis de Filóstrato, como epítome del género, da lugar a una paradoja por la cual el discurso verbal facilita e impide la visión al mismo tiempo, pero también conduce a reflexionar sobre la cuestión de hacer visible lo invisible porque, en última instancia, se trata de una interpretación que recrea aquello que describe (Elsner I995; Squire 20I3). En la práctica, la écfrasis es un sistema no conmutativo de representación verbal de una imagen visual que, en realidad, ni busca ni habilita su reproducción formal; es decir, a partir de una écfrasis de una pintura no se puede reconstruir dicha pintura (Baxandall 1985 ).

En último término, parece que la doctrina clásica mantiene un equilibrio, aunque ciertamente inestable, entre las capacidades semánticas de la palabra y de la imagen. Debe señalarse que, en el pensamiento antiguo, el tema, el argumento de una obra, era el nexo que ponía en contacto la imagen y la palabra; fue la écfrasis la que tendió puentes entre los dos planos expresivos, el visual y el verbal, pero su práctica acaba, paradójicamente, oscureciendo la imagen descrita. En general, puede decirse que con la écfrasis se describía verbalmente el tema representado en las obras visuales (no necesariamente reales) que derivaban, en última instancia, de relatos orales o de textos literarios, esto es, de la palabra. Por ello, a mi entender, la écfrasis no pone de relieve con nitidez la brecha semántica que separa palabra e imagen porque, en definitiva, el medio visual está infrarrepresentado. Con todo, se ha llegado a decir que la historia del arte es la versión moderna de la écfrasis y su desempeño conduce a la misma problemática: verbalizar la imagen (Elsner 2OIO). Solo que, mientras que las descripciones modernas ayudan a comprender la obra de arte, la pretensión de la écfrasis antigua era, lisa y llanamente, la de reemplazar el propio objeto visual (Elsner 1995, 24). Finalmente, es conveniente recordar que esta modalidad retórica vinculada con las artes pervivió en la Edad Media, incluso prosperó en los territorios bizantinos (Maguire 1994, 3), donde se adaptó con éxito a la exégesis de las Sagradas Escrituras.

\section{I.4 Y la imagen devino palabra}

Durante la Tardoantigüedad, el Cristianismo reformula la teoría clásica de la imagen y le confiere un carácter metafísico y teológico. Es verosímil pensar que esta nueva noción cristiana está arraigada en las concepciones hebraicas que habían asociado la palabra con la divinidad. La palabra, el Logos, es el principio creador inmutable, es el Verbo Divino, es una manifestación de Dios que antecede a todo lo visible (vid. Boyarin 2OII): "In principio erat verbum" (Juan I,I). A partir de este presupuesto teológico se produce un cambio en el estatuto de la imagen que la convierte en un texto, la imagen subroga al texto como si fuera su traducción visual, y como texto puede ser leída (vid. Kessler r994a). La Edad Media hereda esta nueva concepción de la imagen, y con ella se introduce el conflicto inherente al rol subordinado que la imagen debe asumir frente a la palabra.

La autoridad de san Agustín fue decisiva al confrontar netamente el valor cognitivo de leer un

Samósata. Cabe mencionar su diálogo sobre la calumnia (c. r6o d.C.), en el que se explica la historia de un tal Apeles, pintor de la corte de Ptolomeo IV Filopator (s. III a.C.), que ha sido objeto de una calumnia que a punto ha estado de costarle la vida. Una vez aclarado el complot, y como recuerdo y venganza, el pintor expresa como mejor sabe, mediante imágenes, una recreación visual con el tema de la calumnia.

8. "Quien no ama la pintura es injusto con la verdad, es injusto con toda la sabiduría que les ha sido dada a los poetas -pues tanto éstos como los pintores contribuyen por igual al conocimiento de los hechos y apariencia de los héroes-y desprecia las proporciones por las que el arte se vincula a la razón.” (Imagines, I,I, traducción Cuenca-Elvira ed. I993, 33). Vid. asimismo Squire 2013. 
texto y el de ver una imagen. ${ }^{9}$ Cuando vemos una imagen nos podemos quedar en la superficie, deleitándonos con sus formas sin profundizar en lo que significa ("picturam cum videris, hoc est totum vidisse"); sin embargo, leer un texto requiere un esfuerzo que no es necesario para ver una

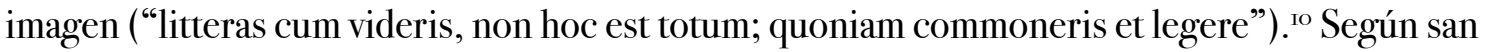
Agustín, tal inmediatez es mucho más sensible a los errores si las respuestas se buscan antes "in

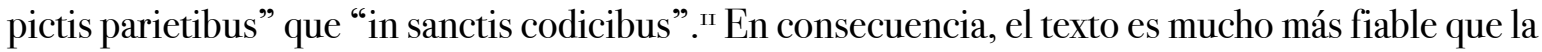
imagen (Cavallo 1994, 36).

En la Edad Media se acentuaron las tensiones entre el texto y la imagen, especialmente en Bizancio, sacudido por graves crisis iconoclastas entre 723 y 843 . Son los mismos territorios donde, sorprendentemente (o, tal vez, no tanto) pervivieron ininterrumpidamente los géneros retóricos clásicos relacionados con las artes visuales, como la écfrasis. Cabe recordar que durante la época medieval, tanto en Oriente como en Occidente, las imágenes religiosas se sitúan en la órbita de las polémicas sobre la Encarnación de Dios. ${ }^{\text {I2 }}$ Tales debates polarizaron las opiniones en dos tendencias extremas: la iconoclastia, es decir, la prohibición de las representaciones de los seres divinos, y la iconodulía, o idolatría de las imágenes. En los territorios del Occidente latino medieval, la aceptación de las imágenes religiosas parece que fue algo menos traumática. Uno de los lugares comunes en la literatura especializada sobre el tema es la explicación de que el cristianismo, al menos el occidental, admitió las imágenes por su valor didáctico, y así las pinturas se convirtieron en los libros de los iletrados. Es la "vía media" del papa Gregorio Magno (590-604), recogida en la célebre correspondencia que mantuvo con el obispo Sereno de Marsella, a finales del siglo VI. ${ }^{13} \mathrm{El}$ papa Gregorio consideraba las pinturas como instrumento de evangelización de las masas rurales; sin embargo, lo que resulta más pertinente para nuestro estudio es su afirmación acerca de que los ignorantes podían adquirir conocimiento gracias a las "historiae" pintadas cuando decía "scientiam historiae colligerent" ${ }^{\mathrm{I} 4}$

Algunos estudiosos han señalado la dificultad que conlleva esta declaración, puesto que implica aceptar que la percepción visual de las imágenes constituye una vía legítima de aprendizaje, comparable a la palabra, ya sea oral o escrita (Duggan I989, 227; Chazelle I990, I44). Otros autores cristianos, como por ejemplo Paulino de Nola, también justifican las imágenes pero sin otorgarles ningún valor como fuente de conocimiento (Duggan I989, 229; Chazelle I990, I44). Según los

9. Según Michael Squire, Agustín "exploted the analogy [entre la palabra y la imagen] in order to champion the supremacy of the language.” (Squire 2013, 98).

IO. Augustinus, In Evangelium Joannis Tractatus, XXIV, 2, PL 35, col. I593.

II. El error más común para San Agustín es que las pinturas muestran hechos que no son auténticos y que no tienen su contrapartida en los textos: "Sic omnino errare meruerunt, qui Christum et Apostolos ejus non in sanctis codicibus, sed in pictis parietibus quaesierunt: nec mirum si a pingentibus fingentes decepti sunt”; y añade que uno de los errores más flagrantes es que Jesucristo no coincidió en vida con San Pablo, tal y como se presenta en las pinturas, “Toto enim tempore quo Christus in carne mortali cum suis discipulis vixit, nondum erat Paulus discipulus ejus" (Augustinus, De Consensu Evangelistarum I, IO, I6, PL 34, col. IO49). Por el contrario, otros autores cristianos, como Prudencio o el papa Gregorio II, mantenían que las historias bíblicas representadas en las pinturas confirmaban la autenticidad de los hechos narrados (vid. Kessler i994a, esp. 357 y n. 2).

I2. Un ejemplo occidental sería la postura iconoclasta de un grupo de teólogos carolingios de origen hispano, especialmente, Claudio de Turín (fl. 8IO-27) y los postulados de la crisis adopcionista. Según Schmitt, la aversión por las imágenes del adopcionismo significaba admitir el misterio de la Encarnación, y con ella la naturaleza humana-y por tanto, visible-de Cristo, lo que abría un resquicio para permitir las representaciones de los seres divinos (Schmitt I987, 278-279).

I3. Entre los estudios de referencia sobre la función didáctica de las imágenes en las epístolas de Gregorio Magno a Sereno de Marsella vid., por ejemplo, Camille ı985, Duggan ı989, Chazelle ı99o, Cavallo ı994, Kessler r994a, Kessler I994b. Sobre la recepción medieval del dictum de Gregorio Magno, vid.. Duggan I989.

I4. Sancti Gregorii Magni, Registri epistolarum, PL 77, Libri IX, CV, cols. IO27C-IO28A. 
especialistas, Paulino de Nola, en realidad, da mayor protagonismo a los tituli explicativos que a las historias pintadas. ${ }^{15}$

Con su afirmación, Gregorio Magno parece recoger la tradición clásica, fundamentalmente griega, que, como hemos visto, equilibraba el potencial semántico tanto de la imagen como de la palabra. ${ }^{16}$ Las afirmaciones de algunos autores cristianos griegos parecen conceder a la imagen un valor similar al texto. Las palabras de Basilio de Cesarea (c. 329-379), por ejemplo, recuerdan el ut pictura poesis en su homilía dedicada a los cuarenta mártires: "Quae enim historiae sermo per auditum exhibet, ea ob oculos ponit silens pictura per imitationem". ${ }^{17}$ Por su parte, Juan Damasceno (c.675-c.75o), campeón de la lucha contra la iconoclastia bizantina, defenderá, un siglo más tarde que el Papa Gregorio, la utilidad del arte como medio de instrucción de los iletrados..$^{18}$ En suma, se han señalado muchos testimonios de la patrística griega que mantienen la tradición anterior de aceptación de las representaciones visuales como complemento de la palabra, sin subordinación explícita. ${ }^{19}$

Las dos epístolas que el papa Gregorio remitió al obispo Sereno de Marsella, aunque breves, parecen ser el corolario de ambas tradiciones, puesto que se afirma que las pinturas no solo pueden ser leídas sino que esa "lectura" proporciona conocimiento nuevo. ${ }^{20}$ Los especialistas han debatido la propuesta de Gregorio Magno acerca de la posibilidad de obtener conocimiento a partir de la contemplación de las imágenes. Entre ellos, Lawrence Duggan hizo una pregunta que puede resultar incómoda: "In other words, can 'reading' of pictures only remind one of what one already knows or can it also, like the reading of books, convey essentially new information?" (Duggan I989, 227). Michael Camille, por su parte, reclamaba más atención a esta cuestión cuando señalaba que, si bien la afirmación de Gregorio Magno se había convertido en un tópico de la historiografía del arte medieval, en realidad no había estimulado una investigación sistemática del tema (Camille 1985).

En resumen, según una tradición historiográfica establecida, la interpretación de San Agustín habría sido fundamental para convertir decididamente la imagen en un texto, gracias al inmenso prestigio del obispo de Hipona. Esta concepción es compartida por otros padres de la Iglesia, lo que facilita que la imagen haya asumido una función propia del texto: las imágenes se leen, pero la calidad de sus mensajes es diferente a la palabra. La "vía media" de Gregorio Magno, al convertir aparentemente las imágenes en una herramienta de apoyo a la catequesis, alejó la atención del aserto más polémico que sugería que las imágenes podían transmitir información de manera autónoma. En los últimos años, la crítica postmoderna ha tratado estas cuestiones desde diversas perspectivas, y ha visto en esta conversión de la imagen en texto, que se consolida gracias a San Agustín, uno de los jalones fundacionales del denominado paradigma logocéntrico occidental, que implica una primacía del texto frente a la imagen; paradigma al que se ha combatido denodadamente con el método de la deconstrucción. Resulta conveniente tener en cuenta las aportaciones del postmodernismo en estos

I5. Paulinus Nolanus, Carmen 27, 5 $5^{\mathrm{II}-595}$, CSEL, $3 \mathrm{O}$.

I6. También se ha señalado, no obstante, que la postura expresada por el papa Gregorio Magno se aleja notablemente de dicha filiación griega (Chazelle I990, I44).

I7. In sanctos quadraginta martyres, 2, PG 3I, cols. 5O7-IO.

I8. De imaginibus oratio I, PG 94, col. I265D, vid. Maguire I994, IO.

19. Herbert Kessler señala que incluso en época iconoclasta se admitieron ciertos ciclos pictóricos, naturalmente aquellos que no representaran la divinidad, porque la pintura completaba el sentido de la escritura (Kessler I994a, 357).

20. Gregorio Magno dice en la primera carta dirigida a Sereno de Marsella: "Idcirco enim pictura in Ecclesiis adhibetur, ut hi qui litteras nesciunt, saltem in parietibus videndo" (Sancti Gregorii Magni, Registri Epistolarum, PL77, Libri IX, Epistola CV, cols. IO27C-IO28A). En la segunda carta se reafirma en sus posiciones: "Nam quod legentibus scriptura, hoc idiotis praestat pictura cernentibus, quia in ipsa etiam ignorantes vident quid sequi debeant, in ipsa legunt qui litteras nesciunt. (...) Frangi ergo non debuit quod non ad adorandum in Ecclesiis, sed ad instruendas solummodo mentes fuit nescientium collocatum.” (Libri XI, Epistola XIII, cols. II28A-II3OB). Las cursivas son mías. 
temas, puesto que sus planteamientos han marcado muchas de las tendencias historiográficas que afectan actualmente a la percepción de la iconografía medieval.

\section{I.5 Dos écfrasis medievales}

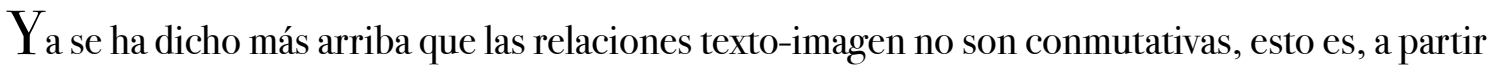
de la descripción textual de una obra no se puede recomponer visualmente su forma original. Como ejemplo se pueden mencionar dos textos medievales que describen sendos baldaquinos monumentales, uno en Sant Miquel de Cuixà (s. XI) y el otro en Santiago de Compostela (s. XII). Estas descripciones literarias, que bien podríamos considerar como écfrasis, son los únicos testimonios de la existencia de dichas estructuras, puesto que ninguna de ellas se ha conservado hasta nuestros días. Tal circunstancia ha favorecido la aparición de numerosas propuestas de reconstrucción, pero aquí solo nos interesan aquellas que se han formulado visualmente.

La carta sermón del monje Garsias (IO43-IO46), escrita con motivo de la consagración de IO4O de la iglesia de Sant Miquel de Cuixà, reformada a instancias del abad Oliba, incluye la descripción de un ciborio que cubría el altar mayor. La carta, perdido el documento original, se conoce por una transcripción de Pèire de Marca (Junyent 1992, 369). Se sabe por dicho documento que el ciborio olibano, al que se denomina propitiatorium, era una estructura que cubría el altar mayor y descansaba sobre cuatro columnas, rematadas con sus respectivas basas y capiteles. Este baldaquino estaba decorado con un Agnus Dei, evangelistas ("sculpsit [...] ligno imagines quatuor evangelistarum") y apóstoles (“duodecim apostolorum") (Junyent 1992, 378). A pesar de los detalles que ofrece esta composición, los especialistas no han podido deducir ni la forma ni la colocación exacta de los elementos. La opinión más generalizada es que la prosa de Garsias es oscura y retórica (Junyent 1992, 385; Orriols I996, 44), pero la descripción del baldaquino es extensa y añade incluso una interpretación simbólica, iconológica podríamos decir, de los componentes de la estructura.

Entre los autores modernos, Puig i Cadafalch (I867-I956) y recientemente, Daniel Codina, Pascale Bourgain y Marianne Besseyre (2009), han intentado hacer una reconstrucción visual del baldaquino. ${ }^{25}$ Se supone que una restitución gráfica del ciborio de Cuixà debería basarse en la descripción del monje Garsias. En el caso de la propuesta “ideal” de Puig i Cadafalch (ı9o9, 406 fig. 353), este autor afirma explícitamente que sus modelos son los baldaquinos que se conservan de los siglos XI y XII; concretamente menciona los ciborios medievales de San Ambrosio de Milán, San Nicolás de Bari, San Clemente de Roma y, especialmente, el altar portátil en forma de baldaquino del rey Arnulfo de Carintia, datado en 89o, que se conserva en el Tesoro del Museo del Palacio de Munich (Puig i Cadafalch I9O9, 408-9). Por consiguiente, la restitución gráfica de Puig i Cadafalch no parte realmente de la descripción textual, sino del aspecto de otras estructuras más o menos contemporáneas. Más recientemente, también se ha propuesto una reconstrucción gráfica del ciborio (Codina-Bourgain-Besseyre 2009, 73); a falta de mayores precisiones por parte de los autores, podría pensarse que se inspira directamente en la descripción del monje Garsias. ${ }^{22}$ Esta última restitución gráfica es muy diferente de la de Puig y Cadafalch, tal vez porque parten de criterios totalmente opuestos.

2r. El baldaquino de Cuixà ha sido objeto de varios intentos de restitución no gráfica a partir de la identificación bien de membra disiecta o bien de ciertos reflejos en otros medios, como la miniatura (vid. Ponsich I993, Orriols I996 o Lorés 2007, I87-I88, por citar algunos ejemplos).

22. La verdad es que estos autores no comentan el dibujo, que simplemente acompaña esta traducción al francés del texto del monje de Cuixà. En la nota 2 hay una breve alusión a la restitución gráfica por la que se deduce una labor colectiva, mientras que el dibujo aparece firmado por Romuald Vigier. 
Finalmente, cabe recordar un apunte muy sugerente de Serafín Moralejo, quien conjeturaba que se podía establecer algún tipo de nexo visual entre el ciborio de Cuixà y el baldaquino que resguarda el arca de la alianza figurado en una miniatura de la Biblia de Rodas (Moralejo 2004a, I77). ${ }^{23} \mathrm{El}$ monje Garsias califica el baldaquino de propitiatorium, evocando así la pieza que fabricó Moisés para cubrir el arca de la alianza (Ex. 25, I7:22). Parece que el miniaturista tenga en mente una fórmula visual como la del baldaquino de Cuixà para ilustrar el propiciatorio bíblico. Si acaso, coincide el color rojo de las columnas que, en la carta de Garsias, simbolizaban los cuerpos ensangrentados de los mártires, y los capiteles blancos, que expresaban la castidad (Junyent I992, 378). La miniatura carece, no obstante, de los elementos figurativos que comenta el monje. Con todo, debe señalarse que la iglesia de Santa María de Ripoll también contaba entre sus bienes muebles del siglo XI con un baldaquino que cubría el altar principal. En efecto, una mención del inventario del tesoro, datado el I9 de marzo de IO47, señala la existencia de un ciborio: "colunas ciborii coopertas argento" (Junyent I992, 396). Sin embargo, las columnas recubiertas de plata tendrían un color que no concuerda con la miniatura. En suma, resulta complicado pronunciarse ante indicios tan elusivos.

Por otra parte, se han señalado ciertas semejanzas iconográficas entre el baldaquino de Cuixà y el ciborio, también desaparecido, que el obispo Gelmírez (c. IO7O-II4O) comisionó para la catedral de Compostela (c. IIO5) (Moralejo 2004a). ${ }^{24}$ El conocimiento del baldaquino gelmiriano se debe a la mención de la Historia Compostelana, ${ }^{25}$ y especialmente, a la descripción del capítulo noveno del Liber peregrinationis, más conocido como Calixtino. ${ }^{26}$ Esta estructura desaparecida también ha inspirado algunas restituciones gráficas, como la de Mayer, que publicó López Ferreiro a principios del siglo XX, calificada como "restauración conjetural" (I9O0, 236), la de Moralejo (2004b) ${ }^{27}$ y, últimamente, una reconstrucción en $3 \mathrm{D}$ (vid. Castiñeiras 2OII, 24). ${ }^{28} \mathrm{~A}$ mi entender, las tres propuestas de restitución gráfica parten, esta vez sí, de la descripción de la "Guía" (vid. Castiñeiras 2OII, 27-28), y por ello, las tres versiones sufren las dificultades de traducir una descripción literaria en una imagen. Uno de los indicios de que las tres propuestas siguen la descripción de la "Guía" como modelo sería las semejanzas que se observan en la estructura básica del ciborio, aunque interpretan de maneras diferentes la morfología del cuerpo superior. ${ }^{29}$ De hecho, tales discrepancias

23. París, Bibliothèque Nationale de France, Ms. Lat. 6(II), f.262. Vid. la miniatura digitalizada en el enlace siguiente: http://tinyurl.com/BNFL62f262.

24. El baldaquino compostelano desapareció en el siglo XV, cuando don Alfonso de Fonseca ordenó sustituirlo en I 462 .

25. La Historia compostelana no describe el baldaquino, al que denomina cibolium; únicamente señala que estaba fabricado en oro y plata $(H C, \mathrm{I}, \mathrm{XVIII})$.

26. Se conoce como Liber peregrinationis el libro quinto del Liber Sancti Iacobi (LSI, V: Moralejo-Torres-Feo 2004). Uno de los testigos más completos y conocidos es el Codex calixtinus (Santiago de Compostela, Archivo de la catedral, s.n.). Aymerich Picaud es el autor de esta "Guía del peregrino", como también se denomina al Liber peregrinationis, y se ha datado la fecha de su redacción entre ıззо у пґ fragmento dedicado al baldaquino en $L S I, \mathrm{~V}, 9,6 \mathrm{O} 2-3$.

27. El dibujo de la propuesta de Moralejo no se ha incluido en la edición de sus artículos de 2004, que es la versión citada.

28. Esta reconstrucción $3 \mathrm{D}$ se ha desarrollado con motivo de la exposición Compostela y Europa: La historia de Diego Gelmírez (20I0) por Tomás Guerrero (Magneto Studio), asesorado por Manuel Castiñeiras.

29. A pesar de tener en cuenta el texto como base para cada una de las propuestas, que es lo que interesa subrayar, es indudable que sus respectivos autores han considerado posibles reflejos de la iconografía del ciborio en otras obras, así como los paralelos contemporáneos. Esto último es lo que se ha hecho para solucionar la composición de la cubierta de la reconstrucción ${ }_{3} \mathrm{D}$ del ciborio gelmiriano y así se hace constar. Como hiciera Puig i Cadafalch, Castiñeiras ha tomado como modelos de inspiración "baldaquinos italianos de los siglos XII y XIII”, por ello su propuesta se inclina por un segundo cuerpo octogonal “que permitía una mejor adaptación de la iconografía descrita por el Calixtino" (Castiñeiras 2OII, 3O). 
son el resultado de las dificultades que conlleva trasladar en imágenes lo que explica el texto.

Serafín Moralejo reflexionó sobre las posibilidades y las limitaciones del Calixtino como una fuente fiable para el historiador del arte (Moralejo 2004b). En ocasiones se ha cuestionado la veracidad de las informaciones vertidas en la "Guía”, y Moralejo ha apuntado como causas, entre otras explicaciones, precisamente a la pervivencia de la écfrasis en el Occidente medieval como modelo literario para los autores de la época que describían monumentos contemporáneos (Moralejo 2004b).

\section{La iconografía y sus límites}

L no está de moda actualmente; en realidad, un amplio sector de especialistas considera, tras más de treinta años de críticas, que es una metodología superada. El desmantelamiento de la credibilidad de la iconografía ha consistido en atacar, desde diversos frentes, la línea de flotación de su propia esencia. Se han censurado especialmente sus posibilidades representativas para traducir en palabras los estímulos visuales; por su parte, la crítica contemporánea se ha encargado de ampliar la brecha consustancial a los dos registros, el verbal y el visual..$^{\circ}$

En realidad, uno de los requerimientos que impone la iconografía es la existencia de, al menos, un tema en la imagen analizada y, justamente, no todas las imágenes ni todo el arte representa un asunto, especialmente gran parte del arte contemporáneo no figurativo. Sin embargo, el análisis iconográfico ha extendido su ámbito de aplicación a otros medios artísticos modernos, como la fotografía y el cine. ${ }^{3 \mathrm{r}}$ Así pues, durante las últimas décadas del siglo XX, la iconografía, tal y como la postulara Erwin Panofsky, ha perdido el estatus que tenía como uno de los métodos más fiables de interpretación al alcance del historiador del arte.

\section{I La iconografía según Panofsky}

Erwin Panofsky (ı892-I968) sistematizó el análisis iconográfico en la famosa introducción a su obra Studies in iconology, publicada por vez primera en 1939 (Panofsky I972, 3-I7). En ella, Panofsky consagra una definición del término iconografía según la cual dicho método "concerns itself with the subject matter or meaning of works of art, as opposed to their form” (Panofsky I972, 3).

3o. Para Baxandall, en realidad el lenguaje no tiene la suficiente capacidad para representar verbalmente una pintura concreta, sino que tan solo puede ofrecer descripciones genéricas. Este autor se hace eco de la crítica repetida al símil horaciano que señala la discrepancia entre la secuencialidad del medio verbal, adaptada a la acción, y la condición de instantánea fija del medio pictórico, en la que todos los elementos coexisten en el tiempo (Baxandall I985, 3). Se trata de un argumento con una larga historia. El primer autor que recuperó la distinción entre la poesía como un arte del tiempo y la pintura como un arte del espacio fue G.E. Lessing en su Laoocon, publicado en I766 (Lee I982).

3r. Se puede añadir que incluso en la actualidad se sigue cultivando el género de la écfrasis. Un ejemplo rabiosamente contemporáneo, que introduce los nuevos medios visuales, el cine y la fotografía, puede encontrarse en el fragmento “I see a rhinoceros!" en la película dirigida por Woody Allen, titulada Midnight in Paris (2OII). En esta película, Dalí (Adrien Brody) anuncia que va a hacer un retrato del protagonista, Gil Pender (Owen Willson) y, a continuación, describe verbalmente cómo será dicha pintura, una pintura que nunca existió; por supuesto, en el cuadro imaginario se incluye un rinoceronte. La auténtica écfrasis, la que induce a la visualización, es, no obstante, la historia que explica el protagonista, de tal manera que el fotógrafo (Man Ray encarnado por Tom Cordier) es capaz de ver una fotografía y el cineasta (Luis Buñuel, Adrien de Van) ve una película gracias a la descripción verbal. Vid. el fragmento reseñado en http://youtu.be/ 4 BEf2nRwKX8. 
Panofsky desarrolló un modelo tripartito que intenta acceder gradualmente, por fases controladas y secuenciales, al contenido de la obra de arte visual. El primer nivel es el preiconográfico, que consiste en la identificación elemental de las formas representadas. El siguiente nivel es el iconográfico, en el que se reconoce el asunto y se establecen relaciones entre motivos artísticos y temas, conceptos o significados convencionales. El estudioso alemán denominó “iconología” al tercer y último nivel. Se trata de la capa más profunda de acceso a los valores simbólicos del contenido de las imágenes: es el dominio de los símbolos culturales. ${ }^{32}$ Un análisis sistemático de la iconografía como el que se ha descrito tiene un gran potencial, puesto que permite ajustar su estructura y sus procesos a un tratamiento catalográfico apoyado en vocabularios controlados; un sistema de esta naturaleza se puede migrar, sin demasiados esfuerzos, al mundo digital, tal y como comentaremos más adelante.

\subsection{Las críticas y las posibilidades del método iconográfico de Panofsky}

Este modelo de análisis iconográfico tuvo un éxito inmenso y varias generaciones de historiadores del arte han usado el legado de Panofsky de manera fecunda. El problema es que, en algunas ocasiones, también ha habido abusos que han desnaturalizado el método. En realidad, se había consagrado la brecha secular entre forma y contenido, puesto que el método iconográfico ignoraba otras aproximaciones, como el formalismo y el análisis estilístico. En efecto, la iconografía, así concebida, conduce a la disociación entre la significación y la forma, pues se centra exclusivamente en la búsqueda del contenido semántico de la imagen. Este rechazo de las formas, al ser entendidas como carentes de significado, constituye uno de los postulados fundamentales del constructo metodológico de Panofsky.

Entre las objeciones al método iconográfico de Panofsky que más nos interesan, debe destacarse la que subraya su logocentrismo, puesto que contribuye a reforzar la idea de que la imagen es una mera ilustración del texto. ${ }^{33}$ La dicotomía extrema entre forma y contenido no solo despoja la imagen de entidad material, sensible, sino que le aplica un reduccionismo extremo en el que su único interés reside en los valores representativos de la imagen y se restringe "à identifier ses figures et ses thèmes.” (Baschet 2008, I59). En lo que concierne a la historia del arte medieval, parece que tanto el sesgo logocéntrico como la analogía entre texto e imagen han ejercido una enorme influencia desde los inicios de la disciplina. Entre los pioneros se puede mencionar a Émile Mâle, que consideraba el arte medieval bajo la especie de una escritura sagrada. Mâle consagró la búsqueda de la fuente literaria que explicase la imagen como la tarea fundamental del investigador (vid., por ejemplo, Mâle ıوı).

32. Panofsky denomina el primer nivel como "primary or natural subject matter", el segundo como "conventional subject matter" y el tercero como "intrinsinc meaning or content" (Panofsky 1972, 5-7).

33. La noción de logocentrismo es un constructo postmoderno para describir lo que se considera proverbial supremacía del lenguaje. El postmodernismo identifica en primer lugar el marco teórico que trata de refutar, al que denomina "paradigma” logocéntrico, parafraseando a Kuhn y su análisis sobre la naturaleza de las revoluciones científicas (Kuhn I986). Una vez identificada la teoría predominante, esto es, el logocentrismo, su rechazo consiste en poner en duda cualquier posibilidad hermenéutica propugnada por las teorías tradicionales del significado. El principio logocéntrico, aplicado al estudio de las obras artísticas, supone que el único acercamiento crítico posible al contenido de la imagen es mediante el lenguaje y, de manera simplificada, mediante la palabra. El logocentrismo y la nítida separación entre continente y contenido ha sido el centro de las críticas y ha suscitado el interés de los teóricos de la imagen del postmodernismo en general, y de la New Art History en particular, que discuten la existencia real de un contenido intencionado en los “objetos visuales” producidos por el hombre. De ahí que el método iconográfico, basado exclusivamente en el significado, se colocara en el punto de mira de las críticas de la teoría del arte (vid. González I999). 
Otra de las reservas hacia el método iconográfico es que su implementación no requiere que la obra sea observada directamente, sino que el análisis puede realizarse a través de sucedáneos visuales, especialmente las fotografías. En efecto, las fotografías han subrogado al objeto en sí y son las que han difundido la imagen más conocida de las obras de arte.

\subsection{El caso de la iconografía medieval}

Se ha dicho más arriba que la iconografía constituye una herramienta excelente para el estudio de las artes visuales de la Edad Media. Por ello, la situación de crisis en que está inmerso desde hace décadas este método también ha afectado a la especialidad del arte medieval. El punto de inflexión, dentro de la historiografía medieval, se marcó durante el congreso que el Index of Christian Art organizó en 1990, titulado Iconography at the Crossroads. Esta reunión, planteada inicialmente como un homenaje a Erwin Panofsky, sirvió en realidad para poner de manifiesto las contradicciones y los abusos del método iconográfico en el estudio del arte medieval (Cassidy ed. 1993). Como afirma el título del congreso, hacia I99o la iconografía se hallaba en una encrucijada vital en su historia y los especialistas eran conscientes de ello. ${ }^{34}$ En realidad, lo que estaba fallando no eran los fundamentos teóricos del método, sino su praxis y los abusos que se cometían, que transformaron lo que se había concebido como un círculo virtuoso en un círculo vicioso. Entre las preocupaciones de los especialistas se mencionaba, precisamente, el estatus epistemológico de la interpretación de las imágenes, mudas, ${ }^{35}$ así como las relaciones entre texto e imagen (Cassidy r993, 3). Concretamente, los textos estaban en el foco de las críticas, puesto que la iconografía, y principalmente, la iconología, dependían excesivamente de la palabra escrita, un terreno en el que los historiadores del arte, al fin y al cabo, se sienten más confortables, puesto que la naturaleza visual de las obras de arte, y sus imágenes, son intratables, irreducibles al registro semántico verbal. La obsesión por encontrar el texto que explique la imagen puede desembocar en esa mala práctica de la iconografía, en primer lugar, porque este acercamiento no siempre es válido y, en segundo lugar, porque se descuidan las audiencias de la obra de arte, puesto que también contribuyen con otros niveles de significación (Cassidy r993, esp. 6-7).

De todas maneras, parece que el método iconográfico, según lo sistematizó Panofsky, se ha atrincherado y ha tomado carta de naturaleza en un período histórico para el cual no parecía destinado. ${ }^{6}$ Los historiadores del arte medieval, que generalmente no pueden identificar a los hacedores de las imágenes de las épocas que estudian, se interrogan sobre el alcance de su papel creador pero, sobre todo, como transmisor de unos mensajes muy concretos a través de los temas figurativos representados. Como dice Maguire, aunque no sabemos nada del papel del artista medieval en esta materia, es el vínculo esencial entre la palabra y la imagen (Maguire i994, 6-7).

Los criterios barajados por la historiografía han oscilado entre un protagonismo desmesurado de "maestros" itinerantes e hiperactivos, y un anonimato irritante de artesanos sin autonomía intelectual ni conciencia estética sobre los objetos que creaban. En este marco explicativo, el comitente ha ido ganado un peso específico enorme, especialmente como autor intelectual, ya sea directamente o por delegación en un experto, de la iconografía de la obra que promociona y

34. Debe decirse, no obstante, que el título del congreso rememoraba una obra fundamental de Panofsky titulada Hercules am Scheidewege ('Hercules at the Crossroads', 'Hércules en la encrucijada').

35. Recuerda el aforismo atribuido a Simónides del "poema pictura loquens, pictura poema silens".

36. Cabe recordar que el subtítulo del Studies in iconology de Panofsky era Humanistic themes in the art of the Renaissance. El Renacimiento, junto con la pintura flamenca, han sido los ámbitos preferidos de la investigación iconográfica (García Avilés 200O, IO3). 
financia. Así pues, en el mundo medieval de las imágenes, el trecho que va desde la concepción de la obra hasta su elaboración física se ha ampliado de manera exponencial, y la participación del artífice medieval casi podría reducirse, si su protagonismo se minimiza totalmente, a la de mero autómata ejecutor. La parquedad e irregularidad de las noticias sobre el funcionamiento práctico de los talleres artesanos medievales es la tónica general del panorama. ${ }^{37}$ Ello no significa que toda la producción medieval sea anónima, puesto que se conocen los nombres de algunos artífices; muchos de ellos perduran en las signaturas de las obras que crearon. ${ }^{38}$ Asimismo, es posible hacerse una idea a partir de las fuentes documentales, lacónicas en la mayoría de los casos, de la tratadística, de vestigios arqueológicos o de las investigaciones sobre materiales; con todo, las sombras predominan sobre las luces. ${ }^{39}$

Ante el desafío que comporta la carencia de datos mínimamente concretos, relativos a los objetos culturales conservados de época medieval, la historiografía actual ha ido construyendo un modelo explicativo del cual se puede extrapolar el proceso creativo,$^{40}$ que implica un acto comunicador, desdoblado, como mínimo, en dos fases y figuras. ${ }^{\text {41 }}$ En una primera fase intelectual, las tareas de concebir y ordenar los temas a representar recaen en una figura letrada, que generalmente pertenece al ámbito de la jerarquía eclesiástica. Según el estado de nuestros conocimientos, se supone que el conceptor del mensaje iconográfico es un consejero del señor o potentado que promueve y financia el encargo de la obra. Ello no impide que, en ocasiones, el promotor y el conceptor iconográfico puedan ser la misma persona (Guardia 2OII, 279-8I). Si, en el proceso creativo, un gran protagonismo recae en el promotor o comitente es porque su identificación puede resultar más sencilla, ya que es susceptible de haber dejado rastro en las fuentes documentales o epigráficas. En la siguiente fase, la materialización física de este programa de imágenes, ideado previamente, es tarea de un artesano anónimo e, incluso, intercambiable..$^{42}$ Por lo demás, los niveles de especialización iconográfica dependerán de las ambiciones y de los recursos económicos de la iniciativa artística.

Por consiguiente, el comitente, vía el agente ideador, es, en realidad, la figura que recibe el mayor crédito en el proceso de transferir la palabra al formato visual que queda plasmada en el programa iconográfico. El problema radica en identificar los mecanismos exactos de esa conversión, que pasa ineludiblemente por las manos del artesano, que materializa visualmente dicho programa. Se ha conjeturado que el conceptor formaliza la iconografía encargada por el comitente bien proporcionando los modelos visuales al operario de turno, o bien indicando verbalmente los temas a representar, pero ya hemos visto cuán difícil es tomar esta dirección que va de la palabra a la imagen en los ejemplos medievales de écfrasis citados más arriba. Cabe considerar el nivel de libertad creativa con la que el artesano podía operar, cuyos límites irían desde la copia servil de los modelos proporcionados por el patrón, hasta el uso exclusivo de apuntes y plantillas de dibujos propios, adaptables a las particularidades del encargo. Este último procedimiento, por otro lado,

37. Se trata, por consiguiente, de una laguna informativa de muchos siglos. La situación mejora para caracterizar el artesanado bajomedieval, ya que contamos con una información más abundante que, a veces, se ha extrapolado a épocas anteriores. Sobre el tema vid., por ejemplo, Guardia 2OII y Mancho 20I2, y la bibliografía que reseñan estos autores.

38. Un número considerable de obras incluyen fórmulas como fecit que, empero, no siempre identifican al artesano sino al promotor que quería dejar constancia de la empresa que financiaba.

39. Agradezco a Roser Piñol, profesora de la asignatura Tècniques Artístiques de la Universitat de Barcelona, las valiosas indicaciones que me ha hecho al respecto.

40. Debe señalarse que las extrapolaciones se han hecho a partir de un corpus en el que muchas veces están ausentes los grandes centros, cuyas características desconocemos.

4I. Seguimos las líneas generales del proceso dibujadas por Milagros Guardia, pero se han aplicado las correcciones particulares para ajustarse al enfoque que aquí se plantea (vid. Guardia 20II, 279-88).

42. Vid. las reflexiones sobre el tema de Carles Mancho (2OI2). 
caracterizaría un sistema de trabajo de taller que tiene un "know how" propio que adapta a los requerimientos del pedido.

En conclusión, puesto que en el análisis iconográfico predomina el tema representado, resulta imprescindible identificar a los responsables del programa figurativo que ejecutará el artífice de la obra. Sin embargo, hay un largo trecho entre el encargo y su realización material porque se produce un desplazamiento de actores que intervienen en la obra. En realidad, el arte medieval se ha convertido en un arte sin artistas, cuyas formas e imágenes constituyen un alfabeto que debe ser transcrito y leído por los historiadores del arte. Desde el punto de vista tanto del estudioso como del conservador, la operación definitiva para convertir el arte medieval en algo legible consiste en transformar la obra y su imagen en un documento.

\subsection{La imagen como documento}

Aby Warburg afirmaba que las obras de arte eran documentos de la expresión ("Dokumente des Ausdrucks”, Warburg I922, I9I). Desde el punto de vista del historiador, se trata de un documento histórico con valor testimonial, esto es, un documento del pasado. Desde la perspectiva de la disciplina de la documentación, las obras de arte son documentos tridimensionales. Por consiguiente, el objeto artístico y/o sus imágenes, despojados de cualquier juicio estético, son susceptibles de convertirse en fuentes documentales, a cuyo estudio se pueden aplicar las técnicas y los criterios de un proceso informativo propio de un centro de documentación (Martín 2002, 2823).

En el caso que nos concierne, el proceso documental otorga, como mínimo, un atributo nominal, un título, a las obras que clasifica para poder distinguirlas de sus congéneres. Los museos, por ejemplo, que se han convertido en los depósitos de muchas obras de arte y objetos culturales descontextualizados, suelen añadir una breve ficha explicativa junto con las piezas exhibidas. El título que aparece inscrito en estos rótulos se refiere, generalmente, al tema representado en la obra, es decir, a su iconografía. En realidad, estos escuetos letreros son la parte pública de un proceso tanto de inventariado y catalogación como hermenéutico. ${ }^{43}$ El título, por muy obvio que parezca, es una breve descripción formulada con palabras que, más allá de sugerir el tema representado en la obra, funciona como una guía para la interpretación (Fischer 1984, 287-8).

Cuando el proceso documental queda circunscrito al análisis iconográfico, el primer paso consiste en aislar los significados primarios y más elementales-o naturales-de la imagen: es el nivel preiconográfico de Panofsky. ${ }^{44}$ A continuación, debe identificarse el tema representado, esto es, la descripción de las historias contenidas en la imagen. Este proceso divide el contenido de la obra visual en una serie de elementos discretos que pueden ser clasificados y ordenados en una taxonomía de registros iconográficos. Con estos registros iconográficos se puede formar un corpus, ${ }^{45} \mathrm{e}$, incluso, un catálogo.

Un catálogo constituye la cara visible de una taxonomía con la que se realiza una ordenación sistemática, que permite establecer límites al objeto de estudio y que consiste en hacer trozos pequeños para su manejo. Con ello se facilita el proceso de categorización que permite establecer relaciones entre los elementos de la taxonomía mediante el uso de criterios de analogía y de

43. Si el tema no se ha identificado, aun así queda constancia del proceso descriptivo con un lacónico "Sin título" (Fischer 1984, 286).

44. Otros autores identifican este estadio, justamente, con el "análisis formal”.

45. Se entiende aquí como corpus a un conjunto organizado de datos, recopilados a partir de ejemplos más o menos representativos de un ámbito determinado, y que sirven de base a una investigación. 
diferencia. En el caso de un catálogo iconográfico, el índice se compone de objetos culturales cuya entrada principal es la imagen. La elaboración de catálogos sistemáticos para registrar los objetos creados por el hombre ha sido una de las principales tareas en las prácticas de conservación de la memoria cultural y artística. Así pues, la conversión de la obra de arte (y sus imágenes) en documentos permite a la iconografía situarse como una herramienta estratégica no solo para la clasificación de objetos culturales, sino para la eficiencia de los procesos de recuperación de información, como se detallará más adelante.

Con todo, la aspiración de los catálogos y repertorios de monumentos, nacidos del ambiente positivista del siglo XIX, era la de clasificar el universo entero. Este ambicioso modelo entra en crisis hacia los años 6 o del siglo pasado. En las últimas décadas del siglo XX, el postmodernismo empieza a cuestionar la naturaleza no solo de los catálogos, sino también de las instituciones que los crean y utilizan, como los museos. A partir de entonces, el universo de la memoria artística se hace ilimitado e incontrolable; de repente, se alcanza la conciencia de que el conocimiento global al que aspiraban las taxonomías positivistas es imposible, y de que la única posibilidad de organizar este universo es la yuxtaposición desordenada de los fragmentos que habían generado estos catálogos: se vislumbra un retorno al estadio del coleccionismo. Esta nueva situación coincide con la pérdida de credibilidad del método de Panofsky e, incluso, compromete sus posibilidades documentales.

\subsection{El Atlas Mnemosyne de Warburg o la "curación" de las imágenes}

En este nuevo marco de referencia se recuperan experiencias que habían quedado marginadas. El ambiente intelectual es más receptivo a las aportaciones de algunos visionarios de la memoria artística, como Aby Warburg (I866-I929) y su Atlas Mnemosyne..$^{6}$ Warburg, historiador del arte, coleccionista de libros y de imágenes, lector de catálogos, creador de una biblioteca especializada que es el núcleo de la conservada actualmente en el Warburg Institute de Londres, se ha convertido en todo un referente de la postmodernidad que cataloga y que se interesa por los archivos y sus prácticas. De hecho, se ha reconstruido la figura de Warburg como la de un precursor de la documentación digital, del hipertexto y de la visualización de imágenes yuxtapuestas sin textos de apoyo.

El "Atlas Mnemosyne” (Bilderatlas Mnemosyne) es el nombre del proyecto que Aby Warburg inició a su regreso del sanatorio psiquiátrico de Kreuzligen, donde estuvo varios años ingresado para tratar su enfermedad mental, de diagnóstico controvertido (Didi-Hubermann 2OI3), y que quedó interrumpido a su muerte, el 26 de octubre de r929. El Atlas Mnemosyne estaba constituido, en la última versión que quedó inacabada, por un conjunto de sesenta y tres paneles que agrupaba más de mil fotografías. ${ }^{4 z}$ Con el Atlas Mnemosyne, Warburg quería mostrar la permanencia de ciertos valores expresivos que sobreviven como un patrimonio sujeto a complejas leyes de transmisión y recepción, por ello la selección de las fotografías no respondía únicamente a criterios estéticos. En su materialidad, el atlas de Warburg constaba de una serie de marcos de metal ligero (Schoell-Glass 200I, I85) o tablones forrados con tela negra sobre los que se fijaban láminas con imágenes, que se organizaban en función de relaciones iconográficas: con este sistema se solucionaba el problema de las comparaciones múltiples que se plantea al historiador del arte

46. Vid. la edición en castellano del Atlas Mnemosyne en Warnke-Brink ed. 2oio. Sobre Warburg como visionario de la memoria artística vid. Martín 2000 y 2004.

47. Existe la posibilidad de hacer una visita virtual al Atlas Mnemosyne gracias a la magnífica contribución de la revista digital Engramma. Se trata de un work-in-progress a cuyas páginas se puede acceder desde el siguiente enlace htp://www.engramma.it/eOS2/atlante/. 
durante las tareas de análisis simultáneo de imágenes. El propio Warburg consideraba al Atlas como un acopio de imágenes, un inventario de formas y también de gestos, con un enfoque comparativo (Warburg 2OIO). Las fotografías no estaban acompañadas por comentarios o títulos, salvo algunas notas coherentes dentro de la multitud de anotaciones fragmentarias (Gombrich I992, 263)..$^{4^{8}}$ Eran documentos visuales conectados por un motivo iconográfico concreto, sin un discurso lineal y sin un soporte textual. Gombrich recuerda que el método de prender fotografías de un lienzo representaba una manera fácil de estructurar el material y reordenarlo en nuevas combinaciones, tal y como Warburg solía hacer para organizar sus fichas y sus libros siempre que otro tema cobraba predominio en su mente (Gombrich I992, 264).

El atlas de Warburg refleja una multiplicidad de conexiones, ya que cada obra no sólo se entendía desde una perspectiva "unilineal" (Gombrich, I992, 264), es decir, no solo se tenía en cuenta el enfoque diacrónico, el antes y el después, sino que cada elemento del atlas formaba parte, al mismo tiempo, de un complejo entramado de relaciones sincrónicas. De hecho, el legado de imágenes y fotografías de Warburg es tan importante como su biblioteca y, como ésta, la ordenación que aplicaba a los tablones móviles dependía del curso de sus investigaciones. En cierto modo, el Atlas Mnemosyne puede que contribuyera a afianzar la curación de su enfermedad mental, ya que, entre los síntomas asociados con sus brotes psicóticos destacaba, según revela el propio Warburg, la incapacidad de conectar las cosas en relaciones causales simples ("daß ich die Fähigkeit, die Dinge in ihren einfachen Kausalitätsverhältnissen zu verknüpfen, verlierte”). ${ }^{49}$ Los paneles con imágenes permitían experimentar con infinitas conexiones iconográficas, así que quién sabe si la "curación” del atlas pudo tener un cierto efecto terapéutico suplementario..$^{\circ}$

\section{El salto de la iconografía al mundo digital}

L a iconografía, como se ha visto, es una herramienta básica para el historiador del arte medieval. Su aplicación introduce, no obstante, una serie de prejuicios sobre las imágenes medievales que, a mi entender, deben ser revaluados cuando se propone su migración al mundo digital. Antes de presentar una sucinta revisión de las experiencias más destacables, se pueden avanzar algunas consideraciones. La primera es que, en entornos digitales, se han implementado con más asiduidad las dos fases iniciales del análisis iconográfico de Panofsky, mientras que el nivel interpretativo, el denominado "iconológico", suele quedar al margen. Por otro lado, el método del Atlas Mnemosyne de Warburg parece haber inspirado numerosas interfaces web de presentación de imágenes; ocurre, sin embargo, que es más bien una feliz casualidad. ${ }^{5}$ Desde el punto de vista de la automatización

48. Sin embargo, Schoell-Glass afirma que los comentarios a los plafones estaban previstos pero que no se escribieron (Schoell-Glass 2OOI, I85). Según Joacim Sprung (2OI4), especialista en Aby Warburg, no hay constancia de que Warburg concibiese el proyecto Mnemosyne en los términos de una “historia del arte sin palabras”; esta idea, sin embargo, se ha convertido en un lugar común en la historiografía.

49. Así se expresa en la postdata de la carta que envía a los directores del sanatorio, fechada el i6 de julio de I92I, tres meses después de su ingreso (vid. Didi-Huberman 20I3).

50. Aquí el término “curación” invoca la acepción actual de “curación de contenidos”, relativa a la selección cuidadosa, incluso al coleccionismo, de información.

5. Sin entrar en detalles, se puede decir que la presentación web de las imágenes en un formato de álbum de miniaturas se debe a la confluencia tanto de razones técnicas como estéticas. En primer lugar, las miniaturas (thumbnail) han servido para representar las imágenes con el menor coste de ancho de banda. De otro lado, la maquetación de las páginas web en forma de álbum se ha inspirado, por analogía formal, en lo que los fotógrafos denominan copia por contacto (“contact sheet”, y también, "contact print”) (Eddy-Mockus I994). Las copias por contacto, del mismo tamaño que los negativos, se combinan en tiras adyacentes sobre una hoja. La ventaja principal 
del análisis iconográfico, los requerimientos de la descripción exhaustiva de la imagen implican fundamentalmente a la capa del tratamiento de la información textual, mientras que la visualización de los resultados gráficos de las búsquedas iconográficas puede reflejarse en una interfaz que imite los paneles del Atlas Mnemosyne. En fin, para conseguir dicha capa de presentación formada por imágenes yuxtapuestas, cuyos vínculos responden a criterios iconográficos subyacentes, es necesario desarrollar una infraestructura basada en la descripción textual de la imagen.

\section{I Los catálogos iconográficos en la práctica digital}

El método iconográfico de Panofsky, con las oportunas revisiones, depuraciones y cautelas, ha mostrado su vigencia y flexibilidad para adecuarse a las funcionalidades de recopilación, sistematización y exposición de catálogos de imágenes en entornos digitales. Numerosos proyectos de catalogación de obras de arte o, simplemente, de imágenes, se basan en los presupuestos metodológicos de Panofsky. Se pueden citar ejemplos como los de Iconclass (http://www.iconclass. nl) o las Categories for the Description of Works of Art (CDWA) de la Fundación Getty..$^{52}$ Iconclass se ha definido como un sistema de clasificación iconográfico basado en una revisión de los presupuestos teóricos de Panofsky (Straten I986). Además, debe señalarse que Iconclass consagra la transformación del objeto cultural en documento, puesto que su organización jerárquica se basa en la Clasificación Decimal Universal (CDU), un sistema utilizado por los documentalistas para clasificar el material de las bibliotecas. En cuanto a la normalización propuesta por la Getty, Patricia Harpring afirma explícitamente que en la CDWA, "subject matter is analyzed according to a method based on the work of Erwin Panofsky". ${ }^{33}$ Incluso el etiquetado colaborativo (social tagging) de imágenes parte de los principios panofskianos de categorización (Golbeck-Koepfler-Emmerling 2OII, I752). Por lo demás, los sistemas computerizados tienen en cuenta los niveles de descripción de Panofsky, de tal manera que su nomenclatura se ha adaptado a las nuevas necesidades y se han recalificado como "genérico", "específico" y "abstracto" (Shatford Layne 2002). ${ }^{54}$

Así pues, la iconografía, como método propio de la historia del arte, ha hecho el salto al entorno digital de la mano de instituciones relacionadas con la conservación patrimonial, como los museos o las bibliotecas. Son estas instituciones las que han generado las bases de datos y los recursos electrónicos adecuados para catalogar imágenes; estos desarrollos han configurado una serie de registros que integran texto e imágenes. Estos ítems se han convertido en la cara visible, el expositor virtual, de los objetos culturales que representan. Cada vez más, dicha información se está poniendo

de la hoja de contacto es que facilita las tareas de selección y clasificación de las fotografías. Por lo demás, en entornos digitales, estas hojas de contacto virtuales, especialmente las que manejan obras de arte, se parecen cada vez más al Atlas de Warburg; vid., por ejemplo, la web explorARTorium (http://www.explorartorium.info/).

$5^{2}$. Iconclass no fue concebido originalmente como un proyecto digital, puesto que se desarrolló y publicó entre las décadas de los 7o y 8 o del siglo XX. Sin embargo, su migración completa al mundo digital se emprendió relativamente poco después, entre I990 y $200 \mathrm{O}$.

53. Recientemente, al CDWA se le ha asociado un vocabulario controlado denominado CONA, acrónimo de Cultural Objects Name Authority ${ }^{\circledR}$ Online, que se puede consultar en línea (http:/ / www.getty.edu/research/tools/ vocabularies/cona/index.html). En cuanto al apartado del tema representado en las imágenes con relación a los estándares de la Getty, vid. el capítulo de Harpring titulado “The language of images: enhancing access to images by applying metadata schemas and structured vocabularies” (Harpring 2002), que se puede consultar en línea en el siguiente enlace: http://tinyurl.com/harpring2002.

54. Shatford Layne habla de accesos al tema basados en la of-ness y la about-ness. Estos términos, que no me atrevo a traducir, atienden respectivamente a los niveles de descripción (¿qué representa?, es un nivel objetivo) e identificación de los temas (¿qué trata?, es un nivel más subjetivo) (Shatford Layne 2002). 
a disposición de una audiencia global, que interacciona con estos registros mediante búsquedas concretas o a través de una navegación aleatoria. Pues bien, uno de los accesos primordiales a la interrogación de estas bases de datos es el campo del tema, o dicho de otra manera, los usuarios, normalmente, buscan imágenes a partir de la iconografía (Hourihane 2005, IO76-IO77; Baca ed. 2002). ${ }^{55}$ Esta práctica es especialmente indicada en el caso del arte medieval, ya que difícilmente se puede recuperar una obra por el nombre del autor que la creó. En este contexto, la descripción del contenido de las imágenes y, especialmente, sus posibilidades de automatización, se revela como una cuestión crucial.

Todo ello ha sido objeto de numerosas aproximaciones que van desde las reflexiones de la historia del arte hasta las prácticas de los documentalistas que se dedican a la catalogación de objetos culturales y sus imágenes..$^{56}$ Una institución tan prestigiosa como la fundación J. Paul Getty Trust, que ha contribuido a la creación de estándares y tesauros para la catalogación de objetos culturales, lleva más de tres décadas investigando sobre estas cuestiones. La Getty ha dedicado sus esfuerzos no solo a establecer la importancia del tema representado como punto de acceso en la recuperación de información de colecciones artísticas, sino también a establecer los principios que deben tenerse en cuenta para su indexación (vid. Shatford Layne 2002; Harpring 2002; Baca et al. 2006, 207234). Estas guías y estándares marcan las directrices para la aplicación práctica del sistema de descripción e indexación de obras de arte según el contenido. Dichas recomendaciones consisten en establecer claramente los dos primeros niveles determinados por Panofsky: la descripción y la identificación. Por el contrario, desaconsejan tratar la interpretación si se carece de la formación adecuada (Baca-Harpring ed. 2008); al fin y al cabo, el nivel "iconológico" es inferencial y, por consiguiente, depende en extremo de la formación cultural del intérprete humano (Enser 2008). El objetivo de este tipo de manuales está condicionado por el ámbito al que sirven, el de la catalogación de colecciones artísticas, y su aspiración es la de facilitar la recuperación eficiente de resultados mediante una descripción tan exhaustiva como precisa. Pero, a diferencia de la catalogación de documentos textuales, que cuentan con normativas estandarizadas, los documentos no verbales carecen de un sistema de clasificación universal a pesar de los esfuerzos dedicados. Como causa primordial se ha aducido la brecha semántica o dificultad para trasladar el contenido visual de las imágenes al lenguaje verbal (Enser 2008, 532-3).

\subsection{Indexar el Arte Medieval}

Los historiadores del arte medieval también han sido seducidos por las oportunidades que pueden ofrecer las llamadas nuevas tecnologías, especialmente en lo que se refiere a la indexación iconográfica de repertorios fotográficos, constituidos con anterioridad o diseñados expresamente para su digitalización. Como ya se ha mencionado, la comparación de imágenes, como recurso de filtrado y categorización, es una de las necesidades inherentes al proceso de investigación del historiador del arte en general, y del medievalista en particular. Por consiguiente, para estos especialistas la gestión de los recursos visuales es una cuestión estratégica. Con todo, la experiencia ha revelado que, a fin de garantizar la eficiencia de la indexación de un tema iconográfico medieval, se deben aplicar ciertos principios correctivos suplementarios, como por ejemplo, el análisis

55. El tema ocupa el segundo lugar, después del autor, en las consultas más frecuentes de los usuarios (vid. Hourihane 2002).

56. Ya se ha señalado más arriba que los objetos culturales y las imágenes en diferentes soportes se han convertido en documentos, de ahí que los especialistas en esta disciplina también se hayan ocupado de estas cuestiones y hayan aportado reflexiones muy interesantes sobre sus prácticas, como se verá más adelante. 
estilístico o las tareas de documentación histórica de la obra analizada (Panofsky I972, esp. I2). Por otra parte, en numerosas ocasiones se ha puesto de relieve la importancia del conocimiento historiográfico en el transcurso de la investigación de los monumentos medievales, puesto que la obra que vemos actualmente es el producto de numerosos filtros ideológicos y de intervenciones que han construido una imagen distorsionada del arte de la Edad Media.

3.2.I Antecedentes ilustres en la indexación iconográfica de imágenes medievales

En el ámbito del arte medieval, se deben destacar algunas experiencias notables en el campo de la indexación iconográfica que han configurado el panorama actual, a caballo entre el mundo de las colecciones de imágenes físicas y las compilaciones virtuales.

El primer proyecto que mencionaremos lleva el sello intelectual del malogrado John Ottaway (1955-1994), investigador del CESCM (Centre d’Études Supérieures de Civilisation Médiévale). Ottaway llevó a cabo una serie de campañas fotográficas sistemáticas para el proyecto de recopilación de un corpus de las pinturas murales románicas situadas al norte de los Pirineos. La iconografía condicionó la realización de las fotografías de dicho corpus, puesto que el objetivo era constituir una base de datos formada por imágenes fotográficas cuyo encuadre obedeciera a un principio sistematizador iconográfico previo (Ottaway 1994, esp. 192). Este criterio preestablecido, aplicado a las directrices prácticas de encuadre de las fotografías, no solo regulaba la planificación de las campañas para recoger el material gráfico, sino que constituía por sí mismo un proceso taxonómico. ${ }^{57}$

En segundo lugar, resultan interesantes los principios metodológicos y la problemática de la indexación iconográfica de los manuscritos de la Biblioteca Vaticana, realizada por Jérôme Baschet (Baschet 1992). Este proyecto constituyó una experiencia práctica para el Groupe Images, dentro de las grandes líneas del marco teórico de la llamada "antropología del arte" aplicada al estudio de las imágenes medievales (Schmitt I99I; Voyer 2OIO). $5^{8} \mathrm{Al}$ margen de que la tecnología escogida, el video $\mathrm{CD}$, no llegó a imponerse en Europa y quedó obsoleta rápidamente, debe señalarse que también se tuvo en cuenta el criterio de un encuadre precoordinado en función de la indexación iconográfica (Baschet 1992, 200). Entre los objetivos del Groupe Images destacaba la formación de una iconoteca informatizada (Schmitt I99I) regida por los mismos principios teóricos que animaban al grupo.

Un tercer proyecto destacable -y en el que estoy involucrada personalmente- está dirigido por la Dra. Milagros Guardia, que lidera el grupo de investigación Ars Picta de la Universidad de Barcelona. Las líneas maestras del programa, centrado en el estudio global y la indexación iconográfica de la pintura mural románica catalana, consisten en la "restitució virtual de les pintures murals a l'edifici per al qual van ser fetes, però també tenint en compte la resta d'elements decoratius i de mobiliari litúrgic, i amb relació amb les funcions que aquells espais acollien.” (Guardia et al. 20I4). La investigación fundamental se complementa con un aplicativo web en el que está previsto constituir un centro documental basado en tres ejes principales: la creación de una

57. Tanto el uso del encuadre como la disposición de imágenes en plafones es un proceso con implicaciones epistemológicas, porque segrega la realidad en unidades aisladas para volver a reorganizarlas en nuevas series, que pueden llegar a ser dinámicas e, incluso, evolutivas. El acto mismo de segregar y enmarcar, de poner límites, ayuda a identificar los contenidos. Un ejemplo interesante de su aplicación a la historia del arte es el Atlas Mnemosyne de Aby Warburg, del que ya hemos hablado abundantemente, donde al proceso de aislamiento por encuadre le sigue el de montaje. Sobre el concepto de cuadro y, por extensión, de encuadre, vid. Hagelstein 2OII.

58. Este grupo formaba parte del GAHOM (Groupe d'Anthropologie Historique de l’Occident Médiéval). Sobre las investigaciones acerca de las imágenes medievales llevadas a cabo por este grupo vid. Schmitt, I99I. 
fototeca, el desarrollo de un catálogo informatizado de las pinturas murales del románico pirenaico y la indexación iconográfica y técnica de dichos conjuntos. En este caso, no solo las fotografías se sistematizan en función de las unidades iconográficas, sino que se está implementando una visualización que sea capaz de mostrar la jerarquización topológica de dichas unidades iconográficas en relación con su emplazamiento arquitectónico. Como se puede ver en el prototipo en el que se está trabajando para el ábside central de Sant Climent de Taüll (http:/ / tinyurl.com/

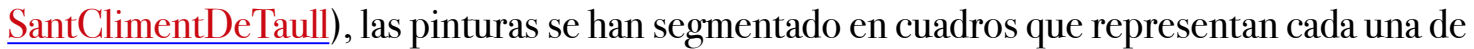
las unidades iconográficas y que se superponen al croquis del ábside, que funciona como base referencial en formato de mapa sensible. Al pasar el ratón por encima del esquema aparecen unos recuadros con su etiqueta correspondiente que señalan dichas unidades temáticas. Si se hace clic en la esquina superior izquierda, marcada por un icono, se muestra una fotografía ampliada de la unidad iconográfica elegida. Se pueden seleccionar varias ampliaciones a la vez, y el usuario puede arrastrar libremente estas imágenes por la pantalla.

Con el transcurso del tiempo, todos estos proyectos de investigación han llegado a confluir en relaciones de intercambio intelectual entre sus investigadores. En las reuniones que se han celebrado periódicamente ha quedado muy claro que descifrar la interpretación iconográfica contribuye a comprender los valores que tenían las imágenes medievales, de ahí la importancia que debe darse a los trabajos de sistematización y catalogación como facilitadores de la investigación fundamental. Por lo demás, el principal problema que enfrentan proyectos como los que se acaban de mencionar es la dificultad para clasificar toda la documentación gráfica recogida durante las campañas fotográficas en unos registros textuales de una manera sistemática y consistente. Como sabemos, la descripción verbal de un "documento" no léxico pone de manifiesto la brecha semántica.

\subsection{Tendiendo puentes para sortear la brecha semántica}

Se ha visto que la descripción y catalogación de las imágenes a partir de su contenido debe hacer frente a inconvenientes y limitaciones considerables, entre los que destaca la dificultad para transferir las características principales de un medio visual no léxico a un medio textual. El obstáculo principal proviene de la llamada "brecha semántica", una especie de indicador que mide la distancia que separa las imágenes de las palabras que, como se ha puesto de manifiesto repetidamente, son dos campos de expresividad diferentes para representar una misma realidad. El concepto de "brecha semántica" (semantic gap) se originó en el campo de las ciencias de la computación para aludir al fenómeno de las discrepancias entre las descripciones de un objeto según el lenguaje utilizado, especialmente, entre el lenguaje humano y el lenguaje computerizado (Jörgensen 2007). Este término se ha aplicado al campo del reconocimento automático de imágenes, como se verá más adelante, y aquí se ha aplicado a las diferencias representacionales entre la imagen y la palabra.

En el caso concreto de la historia del arte medieval, la iconografía resulta como una especie de puente susceptible de superar esa brecha, ya que, de alguna manera, permite conectar la imagen y la palabra. Aunque sea un método tradicional, los especialistas de otras disciplinas han aplicado sus principios básicos. De un lado, los documentalistas que organizan archivos fotográficos o museos, y del otro, los técnicos informáticos que han desarrollado sistemas de bases de datos adecuados para gestionar imágenes, se han enfrentado con desafíos análogos a los que los historiadores del arte encuentran en su rutina investigadora. El diseño de herramientas informáticas para automatizar la recuperación de imágenes según su contenido, esto es, el núcleo duro de la iconografía, se ha enfocado tanto desde la perspectiva de la propia imagen como de textos descriptivos que la 
representen.

3·3.I Las posibilidades del reconocimiento automático del contenido de las imágenes

Las propuestas encaminadas a reconocer automáticamente el contenido de las imagénes (ContentBased Image Retrieval, CBIR) crecieron exponencialmente a partir de la década de los 9o del siglo XX. Con el fin de evitar una cierta confusión causada por la noción de contenido, debe puntualizarse que el dominio del CBIR son los píxeles y no los asuntos figurativos representados en una imagen, su contenido semántico (Enser 2008, 536). Por ello, en la práctica, los resultados obtenidos con este tipo de búsquedas automatizadas no van encaminados a reconocer los temas representados en las imágenes.

Una de las líneas de experimentación utiliza como muestra una imagen para encontrar otras afines; es lo que se denomina búsqueda de imágenes mediante ejemplos o por similaridad. Empresas del calado de Google están trabajando en este sentido y ya se pueden hacer consultas de imágenes por similaridad en su buscador. ${ }^{59}$ Debe mencionarse la existencia de otros proyectos análogos, como TinEye Reverse Image Search (http:// www.tineye.com). Los algoritmos subyacentes a estos buscadores están cada vez mejor afinados.

La automatización en el análisis de las imágenes, como hacen los buscadores que acabamos de enumerar, se basa en el paradigma de la imagen digitalizada, que se compone de píxeles, y el reconocimiento de patrones de los atributos llamados de bajo nivel o propiedades sintácticas, tales como los colores, las texturas, los contornos, etc. Con estos datos se pueden desarrollar algoritmos y procesos automáticos que midan y cuantifiquen, por ejemplo, la distribución de las áreas de un color determinado respecto al resto de otros colores presentes en la imagen. Ahora bien, los resultados que proporcionan estos mecanismos automáticos de filtraje y recuperación de imágenes no son, todavía, demasiado útiles para los historiadores del arte. Precisamente, lo que la tecnología no ha conseguido es obtener resultados satisfactorios en el reconocimiento automático de los temas representados en la imagen, considerados atributos de alto nivel o propiedades semánticas (Hare et al. 2006; Enser 2008, 537). Los trabajos en CBIR han revelado la distancia que separa el reconocimiento computerizado del contenido de las imágenes frente a los sistemas humanos de identificación de los objetos y temas representados en ellas; en definitiva, los avances del CBIR han llegado al umbral de la brecha semántica.

En la línea de este tipo de investigaciones, cabe mencionar una experiencia concreta en el ámbito de la historia del arte medieval, llevada a cabo por dos equipos, uno de historiadores del arte y otro de técnicos del sector de las TIC (Tecnologías de la Información y Comunicación). Hace unos años, el CESCM, junto con un laboratorio especializado en imagen, desarrollaron un proyecto ambicioso que pretendía reconocer automáticamente las imágenes medievales por su contenido (Content Based Image Retrieval), al tiempo que se realizaba una indexación semántica (Angheben et al. 2005). Al margen de los escasos resultados prácticos, este proyecto ha permitido constatar que los recursos tecnológicos disponibles para la automatización de la lectura iconográfica del arte medieval no aportan ventajas significativas a la indexación humana (Angheben et al. 2005, 2I). ${ }^{60}$

Por otro lado, la "brecha semántica" entre el texto y la imagen queda expuesta de manera particularmente evidente en el ámbito de Internet. Los robots web (web crawlers) que inspeccionan

59. Vid. cómo funciona la búsqueda por imágenes de Google en el siguiente enlace http://www.google.com/ insidesearch/features/images/searchbyimage.html.

6o. Si acaso, el reconocimiento automático del contenido de las imágenes tiene más posibilidades en el campo del análisis formal (Angheben et al. 2005, 2ISs). En este sentido se han dirigido esfuerzos recientes para desarrollar algoritmos que permitan reconocer estilos pictóricos (Wallraven et al. 2009). 
las páginas web de forma automatizada, pueden extraer y procesar cualquier contenido textual, especialmente los enlaces incluidos en ellas. Ahora bien, cuando estas páginas contienen imágenes, el robot es incapaz de tratar su contenido a menos que se haya especificado una etiqueta, en formato textual, que haga alusión al título de la imagen o bien a alguna característica de su contenido temático. Sin estas etiquetas, las imágenes son invisibles e irrecuperables en Internet.

Esta incapacidad para reconocer los contenidos de las imágenes que distingue a las máquinas de los humanos puede evaluarse mediante el Test de Turing. Alan Turing (I9I2-I954), uno de los padres de la computación, se preguntaba si las computadoras podrían llegar a pensar; de hecho, Turing opinaba que, con el tiempo, las máquinas podrían adquirir habilidades propias de los humanos y, así, rivalizar con las personas en muchas tareas cognitivas. Para responder a este interrogante propuso, en r95o, una prueba que permitía validar la "inteligencia" de la máquina, el Test de Turing (Turing 1950): cuando una máquina supere la prueba y un humano sea incapaz de distinguir su actuación de la de otro humano, entonces esa máquina deberá ser considerada inteligente. En el mundo actual todavía no existen computadoras que pasen dicha prueba. Mientras tanto, se han desarrollado algunas aplicaciones concretas del Test de Turing que permiten discernir si al otro lado hay una máquina o una persona. Entre estas aplicaciones, se deben mencionar aquellas que permiten controlar el "spam" mediante pruebas como el Captcha (acrónimo de Completely Automated Public Turing Test to Tell Computers and Humans Apart). Interesa subrayar que estas pruebas se basan en imágenes cuyos contenidos aparecen tan distorsionados que solo pueden ser interpretados por un interlocutor humano. En Internet, el Captcha es la verificación cotidiana de la "brecha semántica" que separa las imágenes de las palabras.

Así pues, y hasta donde conozco, todavía no se han implementado algoritmos capaces de identificar que ciertas combinaciones de líneas y de colores conforman figuras humanas y reconocer que, además, se trata de un santo determinado o de un personaje del Antiguo Testamento, por poner unos ejemplos convenientes para el medievalista. En resumen, por el momento es casi utópico pensar que tales algoritmos lleguen a identificar y categorizar la iconografía de las imágenes de obras de arte como lo haría un especialista. En la situación actual, resulta más conveniente para el historiador del arte medieval explotar las ventajas de mecanismos sobradamente contrastados, como la iconografía acompañada por un aparato terminológico consistente basado en los vocabularios controlados, los tesauros y las ontologías. ${ }^{6 \mathrm{E}} \mathrm{El}$ principio fundamental para organizar el acceso por temas a una colección de obras de arte o de imágenes es la sistematización terminológica de los temas representados. Esta sistematización se consigue en el ámbito de la documentación mediante vocabularios controlados y tesauros, y en el mundo de la informática y la web semántica a través de las ontologías. ${ }^{62}$ Estas herramientas documentales se han aplicado a la indexación iconográfica, que también se ha migrado a entornos digitales y, en último término, a Internet y a lo que se denomina la Web Semántica.

\subsection{Los principios de la indexación iconográfica}

La descripción verbal del contenido de una imagen se realiza, irónicamente, para darle

"visibilidad", es decir para que la imagen sea encontrable a partir de su contenido temático. Los

6I. Existe una bibliografía especializada considerable, tanto sobre la automatización de las búsquedas de contenido de las imágenes como sobre las búsquedas a partir del tema o de la descripción de una obra de arte mediante tesauros y vocabularios controlados. Aquí no se ha pretendido, en modo alguno, hacer un estado de la cuestión de estos temas.

62. En el ámbito de la informática, se puede definir una ontología como un vocabulario formalizado de un dominio del conocimiento. 
documentalistas que indexan documentos no léxicos han puesto de manifiesto las dificultades prácticas de conversión entre ambos registros semánticos. La especialista en este campo, Elaine Svenonius, resume la problemática concisamente: "There are instances where a message expressed in one medium cannot adequately be transposed to another" (Svenonius 1994, 60I). Es muy revelador que el axioma principal en las tareas de catalogación de documentos visuales sea el siguiente: "lo que se puede nombrar se puede indexar". ${ }^{63}$

Asimismo, debe tenerse en cuenta que, en muchas ocasiones, el tema de una obra de arte trasciende la simple identificación de las formas representadas. Esta situación no solo compromete las reglas de la indexación, sino también su eficacia. Es un fenómeno característico del arte de temática religiosa, el más frecuente en las investigaciones de los historiadores del arte medieval, puesto que los sistemas simbólicos que manejan las religiones conllevan unas posibilidades referenciales tan variadas y ambiguas que dificultan cualquier esfuerzo taxonómico. Svenonius pone el ejemplo de la simbología del agua en el cristianismo, y sugiere que, cuando aparece en una imagen, resulta muy complejo discriminar con precisión su valor referencial exacto. Una indexación desacertada de las imágenes puede comprometer su recuperación. Por un lado, una descripción insuficiente del tema representado puede provocar "silencio documental". Por otro, se puede generar demasiado "ruido" si se indexan todas y cada una de las posibles interpretaciones (Svenonius 1994, 603). Ante tales inconvenientes se han propuesto alternativas que superen o, mejor, que obvien el método iconográfico de Panofsky para garantizar una descripción y catalogación universal (Winget 2009). Este tipo de propuestas rechazan la concepción del arte bajo la especie textual y, en consecuencia, niegan que el tema sea un punto de acceso relevante a la interrogación de catálogos de objetos artísticos. Tal vez este planteamiento sirva perfectamente a las producciones culturales contemporáneas, pero, para los medievalistas, la iconografía sigue siendo una herramienta descriptiva de primer orden en sus investigaciones.

\subsection{De taxonomías y tesauros: casos prácticos}

El principio fundamental para organizar el acceso iconográfico es la indexación con palabras clave. El tratamiento documental implica, generalmente, una normalización terminológica que se estructura mediante vocabularios controlados formados por descriptores. ${ }^{6}$ Los constructos clasificatorios más comunes son las taxonomías, los tesauros y las ontologías. En este apartado solo se contemplan las taxonomías y los tesauros porque contamos con algunas experiencias prácticas de su uso en el campo de la historia del arte y de la iconografía medievales. Una taxonomía permite clasificar de forma jerárquica los descriptores utilizados para la descripción iconográfica, mientras que un tesauro da acceso a una verdadera representación sistemática de un dominio particular del conocimiento. ${ }^{6}$ La taxonomía consta de descriptores que se pueden organizar temáticamente, tiene una estructura jerárquica y admite facetas que dotan de mayor dinamismo a la categorización. Un tesauro es un vocabulario "de un lenguaje de indización controlado organizado formalmente con objeto de hacer explícitas las relaciones, a priori, entre conceptos” (UNE 5O-Io6-9o I99o, 5) ${ }^{66}$ Además de la normalización terminológica, el tesauro profundiza la clasificación mediante

63. "What can be named can be indexed" (Svenonius i994, 603).

64. Un descriptor es una palabra clave normalizada.

65. Una taxonomía es, en rigor, una clasificación. La preferencia terminológica parece derivar del prestigio de ciencias como la biología (vid. Codina-Pedraza-Jiménez 2OII, 557).

66. También interesa reseñar la definición que da la NISO, para quien un vocabulario controlado "is used to improve the effectiveness of information storage and retrieval systems, Web navigation systems, and other environments that seek to both identify and locate desired content via some sort of description using language. The primary purpose of 
relaciones semánticas. Las más frecuentes son las relaciones de equivalencia, cuando se establecen los descriptores que se han de utilizar frente a otros sinónimos o cuasisinónimos. Un tesauro también contempla las relaciones jerárquicas, cuando van de lo más genérico a lo más específico, y las relaciones asociativas cuando se establecen conexiones entre los términos normalizados. En fin, un tesauro también puede incluir notas aclaratorias breves.

Los tesauros de referencia para la catalogación de obras de arte son el Art \& Architecture Thesaurus (AAT) (http://www.getty.edu/research/tools/vocabularies/aat/) y el Cultural Objects Name Authority ${ }^{\circledR}$ Online (CONA) (http://www.getty.edu/research/tools/vocabularies/ cona/index.html), compilados bajo los auspicios de la fundación J. Paul Getty Trust. ${ }^{67}$ Se trata de vocabularios estructurados de términos genéricos relacionados con el arte y la arquitectura pero no contienen descriptores iconográficos. Con todo, la estructura "sindética" de estos tesauros es un modelo a seguir para los proyectos centrados en el arte medieval. Iconclass, por su parte, también está considerado como un tesauro pero no cumple algunos de los requisitos que los caracterizan, más bien podría decirse que se trata de un sistema de clasificación taxonómico con una estructura jerárquica, algo rígida en mi opinión.

Un instrumento de clasificación específico del ámbito del arte medieval es el Thésaurus des images médiévales pour la constitution de bases de données iconographiques, creado por el Groupe d'Anthropologie Historique de l'Occident Médiéval (GAHOM), y cuya primera edición se publicó en r993. La versión actual de este tesauro se denomina Thésaurus des Images Médiévales en Ligne (TIMEL), desarrollado conjuntamente entre el GAHOM y el Centre d'Études Supérieures de Civilisation médiévale (CESCM), y se puede consultar en línea (http://www.mshs.univ-poitiers.fr/ thesaurus/).

El Thésaurus des Images Médiévales en Ligne (TIMEL) está pensado para indexar un dominio muy concreto: el de las imágenes medievales. Por esta razón el TIMEL aspira a ser la herramienta marco, susceptible de adaptarse a todas las investigaciones que requieran de una labor de catalogación de obras figurativas medievales y sus imágenes. Este sistema tampoco pretende cubrir el nivel interpretativo, sino que circunscribe su ámbito de aplicación a los niveles descriptivos del análisis iconográfico (GAHOM I993). La clasificación previa o precoordinada por facetas (temas, personajes, lugares, elementos naturales, objetos, inscripciones, decoración), así como la jerarquización minimalista, recuerdan mejor a una taxonomía que a un tesauro, aunque se hace especial hincapié en la necesidad de normalizar los descriptores.

Estos tesauros se integran en el desarrollo de bases de datos para gestionar colecciones de imágenes digitales. Una de las implementaciones destacables del tesauro GAHOM-TIMEL es la base de datos iconográfica Prealp para documentar las pinturas murales alpinas de los siglos XIII al XVI (Rigaux 1994). La versión más reciente del proyecto se puede consultar en el siguiente enlace: http://prealp.msh-alpes.fr/fr/iconographie. La búsqueda iconográfica forma parte de una larga lista de atributos de la ficha de cada obra. El concepto metodológico clave es la unidad icónica, por lo que el enfoque iconográfico, el tema representado, constituye el núcleo de la ficha ${ }^{68}$ Los temas iconográficos se han clasificado siguiendo las categorías de base del GAHOM-TIMEL (personajes, ambientes, objetos, etc.) y, por cuestiones inherentes a un proyecto que afecta a tres comunidades linguísticas alpinas, se ha organizado un tesauro trilingüe.

vocabulary control is to achieve consistency in the description of content objects and to facilitate retrieval." (ANSI/ NISO 20 IO, I). Como se advierte, en este estándar ya se contempla la aplicación a un entorno web y se señala claramente que la descripción mediante el lenguaje es la base de un tesauro.

67. Recientemente la Getty ha liberado el AAT para su acceso como linked open data (http://blogs.getty.edu/iris/ art-architecture-thesaurus-now-available-as-linked-open-data/).

68. Vid. una documentación detallada en http://programmeprealp.msh-alpes.fr/fr/base-donnees. 
La cuestión de los idiomas es otra de las problemáticas que se plantean en el momento de constituir un tesauro, puesto que no se puede obviar la distribución plurilingüe de las comunidades científicas dedicadas al arte medieval. Por ejemplo, el grupo de investigación Ars Picta de la Universidad de Barcelona, dirigido por la Dra. Milagros Guardia, tiene a su cargo la realización de la traducción catalana del TIMEL, desarrollado inicialmente en francés. Esta situación afecta no solo a los idiomas modernos, sino a las lenguas habladas en la Edad Media, especialmente el latín, el griego y, seguramente, el árabe y el hebreo, si nos ceñimos al contexto europeo. Justamente una de las carencias de los repertorios iconográficos tradicionales de arte medieval es el olvido de temas bizantinos, y, por consiguiente, su ausencia en las listas de temas iconográficos; es decir, también en la elaboración de las herramientas iconográficas se advierte una neta separación entre el mundo artístico medieval occidental y el bizantino (Lazaris i996).

Dejando de lado la problemática de categorizar la actividad artística por comunidades religiosas, el arte hebreo cuenta con el repertorio digital The Bezalel Narkiss Index of Jewish Art (http://cja. huji.ac.il/browser.php), que podría entenderse como la versión judía del Index of Christian Art. Este catálogo, que excede el ámbito medieval, contempla el tema representado como una de las entradas esenciales a la base de datos, concebido como un tesauro iconográfico. Éste se ordena primero de manera alfabética, y luego, muchos descriptores proponen términos relacionados, discriminan el uso preferencial de unos términos con respecto a otros, e incluyen subcategorías conceptuales para ampliar o restringir las búsquedas. ${ }^{69}$

Las prácticas asociadas a proyectos de este tipo han generado algunos estudios sobre el comportamiento de los usuarios que, cuando menos, han permitido evaluar las posibilidades y los límites de la descripción iconográfica de las imágenes medievales en su adaptación al mundo digital (Chen 200I)..$^{70} \mathrm{Se}$ puede decir que estos sistemas expresan, en mayor o menor medida, los síntomas de la brecha semántica. Entre los problemas más habituales que exhiben se puede mencionar la frustración de los usuarios cuando no obtienen los resultados esperados que, o bien no se corresponden con la búsqueda realizada, o bien son demasiados (ruido) o no aparece nada en absoluto (silencio documental). ${ }^{71}$ Una de las causas de estos fallos asociados a la brecha semántica son las discrepancias entre el usuario y el especialista indexador al describir una imagen (Hare et al. 2006). Otra carencia habitual es que los resultados no muestran imágenes relacionadas para realizar comparativas o sugerir itinerarios alternativos. La literatura científica que ha estudiado diferentes mecanismos para minimizar la brecha semántica recomienda que el usuario debe ser el centro del diseño de estos sistemas (Hare et al. 2006), una perspectiva completamente ignorada en el desarrollo de colecciones iconográficas, especialmente las de arte medieval, en las que la figura del experto iconógrafo suele ser incuestionable (vid. Hourihane 2002).

69. Aquí simplemente se han citado algunos ejemplos que, para no agotar al lector, deben considerarse como una muestra del panorama general. Conviene subrayar que solo se han mencionado repertorios o tesauros iconográficos libremente accesibles desde Internet. Por ejemplo, el Index of Christian Art, seguramente el repertorio iconográfico de referencia dedicado al arte medieval, cae fuera de este sondeo porque únicamente se puede consultar en línea mediante un muro de pago (vid. http://ica.princeton.edu/index.php). Otros compendios, como el de Garnier (I984) no se han migrado nunca al mundo digital como tales, pero ello no quiere decir que sus listas de temas medievales no hayan servido para construir vocabularios controlados incluidos en numerosas bases de datos iconográficas, como el Portail des collections des musées de France Joconde (vid. http://www.culture.gouv.fr/documentation/joconde/fr/recherche/ aide-icono.htm ).

7o. La literatura científica sobre el tema es tan abundante que la presente contribución ni siquiera se plantea hacer un estado de la cuestión sobre estas materias; vid. en todo caso Enser 20o8. Para el estudio de un experimento concreto con imágenes de época medieval vid. Chen 200 .

7I. Debe advertirse que se han extrapolado los datos reportados en otros contextos diferentes al arte medieval, pero se trata de una cuestión, hasta donde conozco, escasamente investigada en este campo concreto. 
En los últimos tiempos, los esfuerzos se han encaminado a enriquecer el modelo conceptual combinando la descripción semántica del contenido con el contexto de la imagen. Sin embargo, este modelo conceptual también se fundamenta en los descriptores propuestos por indexadores iconográficos expertos. Por lo demás, estos sistemas son extremadamente sensibles a las percepciones de los individuos y los descriptores resultantes pueden llegar a ser inútiles si los usuarios no buscan imágenes con las mismas palabras que ha propuesto el indexador. Esta circunstancia obliga a revisar la suposición de que un tesauro o vocabulario controlado preestablecido sea realmente de utilidad para describir una imagen: en definitiva, hay mensajes que se transmiten mediante imágenes que no se pueden capturar con palabras (Enser 20o8, 533-4). Pero el problema más importante es que la construcción de estas herramientas es muy exigente y tiende a restringirse a dominios muy concretos (Enser 2008, 539), incluso dentro de una misma disciplina, como hemos visto con el "olvido" de temas bizantinos en los vocabularios controlados de arte medieval. De todos modos, el predominio de herramientas digitales pensadas para la Web Semántica ha facilitado la implementación de tesauros en ontologías.

Así pues, las tendencias actuales se enmarcan en el contexto de la Web Semántica, con experiencias basadas en la construcción de ontologías formalizadas, modelos de facetas o el "etiquetado social”, con el objeto explícito de levantar puentes para sortear la brecha semántica. El futuro es prometedor y este debería ser el camino a seguir también en el arte medieval, lo que significaría su integración plena en las llamadas Humanidades Digitales.

\section{Conclusiones}

El hilo argumental de este ensayo ha esbozado, alternando puntos de mira distintos, la problemática fundamental con la que se enfrentan muchos historiadores del arte, entre ellos los medievalistas, en su quehacer investigador. La dificultad consiste en convertir en palabras los temas representados en los objetos visuales que estudian. Para ello, los especialistas cuentan con la iconografía como apoyo metodológico, con el fin de extraer información verbal de las imágenes. Una de las premisas fundamentales del método iconográfico es que se pueden reconocer los asuntos expresados en las imágenes porque estas se basan generalmente en una fuente textual; en definitiva, el objetivo último de la iconografía es encontrar dicho texto.

La génesis del método se remontaría al cultivo de la écfrasis en la Grecia antigua; con todo, dicha filiación se podría calificar de espuria. La Edad Media, una época con una mayoría de iletrados, consagraría la transformación de la imagen en un texto. En cualquier caso, el argumento que se ha querido subrayar es el rol de la iconografía como el puente que permite conectar la palabra con la imagen que, por naturaleza, pertenecen a dos sistemas semánticos diferentes. Se trata de una función tradicional que, con la formalización del historiador del arte Erwin Panofsky, ha servido como punto de partida al desarrollo de herramientas digitales, especialmente bases de datos, que consideran la descripción precisa del tema representado en las imágenes como un elemento estratégico en las búsquedas de los usuarios. Este hecho justifica la vigencia del método en una disciplina, la historia del arte medieval, que busca renovarse también con las nuevas tecnologías en el marco de las Humanidades Digitales.

Las variadas y fecundas aproximaciones al arte medieval desde la perspectiva académica conviven, hoy en día, con una sobreabundancia de material medieval que circula por Internet y que es consumido ávidamente por un público aficionado y fascinado con las imágenes de la Edad Media. Los niveles informativos que ofrece este imaginario son tan diversos como las audiencias del siglo XXI. En este nuevo marco de referencia, la disciplina concurre con una visión postmoderna que 
ha ido relegando el método iconográfico en favor de nuevas y diferentes aproximaciones al objeto artístico. Los especialistas de otras disciplinas, especialmente los documentalistas, o instituciones como los museos han experimentado con el método iconográfico y han analizado su eficacia y sus limitaciones para representar las imágenes en palabras. Esta es la misma problemática que enfrenta cualquier iniciativa para catalogar digitalmente la cultura artística medieval, o simplemente imágenes, y automatizar el acceso y la recuperación de información relevante. El éxito de estas empresas podría permitir nuevas incursiones tecnológicas encaminadas, por ejemplo, a explorar sistemáticamente el éxito y la influencia, o la distribución geográfica, de las diversas temáticas figurativas en época medieval y generar nuevas visualizaciones de esos datos.

Todas estas prácticas han configurado el panorama actual en el que se ha evidenciado más que nunca la brecha semántica que tanto dificulta la traducción de las imágenes en palabras. En este contexto, la iconografía, redefinida y adaptada a los nuevos medios, se ha mostrado una herramienta eficaz, y el tema representado protagoniza uno de los puntos de acceso principales en la búsqueda de imágenes. En el marco digital, y especialmente en Internet, el escaso protagonismo de la academia y de los historiadores del arte medieval en la constitución de colecciones digitales resulta cuando menos significativo, pese a la existencia de algunos proyectos dignos de mención, mientras que la filología, la arqueología, la historia o la paleografía medievales se han acomodado perfectamente a los nuevos medios, y copan la mayoría de los proyectos que se emprenden en el dominio de las Humanidades Digitales.

\section{Obras citadas}

AENOR, I99O, UNE 5O-Io6-9o. Documentación. Directrices para el establecimiento y desarrollo de tesauros monolingües, Madrid, AENOR.

Angheben, M.; Palazzo, E.; Dombre, J. et al., 2005, "Images médiévales et nouvelles technologies de l'information : lecture d'images et indexation par le contenu”, Le Médiéviste et l'Ordinateur, Paris, CNRS-IRTH, http://lemo.irht.cnrs.fr/varia/images-ntic.htm (checked 29-O5-2OI4).

ANSI/NISO, 20IO, ANSI/NISO Z39.19-2005 (R2010): Guidelines for the construction, format, and management of monolingual controlled vocabularies, I3-O5-2OIO, Baltimore, American National Standards Institute, http://www.niso.org/apps/group_public/project/details.php?project $\underline{\mathrm{id}=46}($ checked 29-O5-2OI4).

Baca, Murtha, ed., 2002, An introduction to art image access: Issues, tools, standards, strategies, Los Angeles, Getty Research Institute, http://tinyurl.com/Baca2OO2 (checked 29-O5-20I4).

Baca, Murtha; Harpring, Patricia; Lanzi, Elisa et al., ed., 2006, Cataloging cultural objects: A guide to describing cultural works and their images, Chicago, American Library Association, http:// cco.vrafoundation.org/index.php/toolkit/cco pdf version/( checked 29-O5-2OI4).

Baca, Murtha; Harpring, Patricia, ed., 2008, Categories for the description of works of art, Los Angeles, J. Paul Getty Trust-College Art Association, http://tinyurl.com/BacaHarpring2008 (checked 29-05-2014).

Baschet, Jerôme, I992, "Les vidéodisques des manuscrits de la Bibliothèque Vaticane et la réalisation d'une base de données iconographique”, Arte Medievale II Serie, 6-I, I99-2O4. 
Baschet, Jerôme, 2008, L'iconographie médiévale, Paris: Gallimard.

Baxandall, Michael, 1985, Patterns of intention: On the historical explanations of pictures, New Haven, Yale University Press.

Belting, Hans, 2009, Imagen y culto: una historia de la imagen anterior a la era del arte, Madrid, Akal (I990).

Boyarin, Daniel, 20II, “Logos, a Jewish word: John's prologue as midrash”, en The Jewish annotated New Testament, Amy-Jill Levine, Marc Z. Brettler ed., Oxford, Oxford University Press, 546-49.

Bredekamp, Horst, 2003, "A neglected tradition? Art history as Bildwissenschaft", Critical Inquiry 29, 418-28.

Cuenca, L. A. de; Elvira, M. Á., ed., I993, Calístrato; Filóstrato el Joven; Filóstrato el Viejo Imágenes. Descripciones, Madrid, Siruela.

Camille, Michael, 1985, "Seeing and reading: Some visual implications of medieval literacy and illiteracy”, Art History 8-I, 26-49· http://dx.doi.org/IO.IIII/j.I467-8365.I985.tbooI48.x

Cassidy, Brendan, ed., I993, Iconography at the crossroads: Papers from the colloquium sponsored by the Index of Christian Art, Princeton University 199o, Princeton, Princeton University Press.

Cassidy, Brendan, I993, "Introduction: Iconography, texts, and audiences", en Iconography at the crossroads: Papers from the colloquium sponsored by the Index of Christian Art, Princeton University 199o, Brendan Cassidy ed., Princeton, Princeton University Press, 3-I5.

Castiñeiras, Manuel, 2OII, "El altar románico y su mobiliario litúrgico: frontales, vigas y baldaquinos", en Mobiliario y ajuar litúrgico en las iglesias románicas, P. L. Huerta ed., Aguilar de Campoo, Fundación Santa María la Real, II-75.

Cavallo, Guglielmo, I994, "Testo e immagine: una frontiera ambigua”, en Settimane di studio del Centro Italiano di Studi sull'Alto Medioevo: XLI, Spoleto, CISAM, 3I-64.

Cerro Calderón, Gonzalo del, ed., I989, Dión de Prusa, Discursos XII-XXXV, Madrid, Gredos.

Chazelle, Celia M., I99o, "Pictures, books and the illiterate: Pope Gregory I's letters to Serenus of Marseilles”, Word \& Image 6, I38-53. http://dx.doi.org/IO.IO80/O2666286.I990.IO435425

Chen, H., 2OOI, "An analysis of image queries in the field of art history", Journal of the American Society for Information Science and Technology 52-3, 260-73. http://dx.doi.org/IO.IOO2/I5322890(2000)9999:9999<::AID-ASII6o6>3.0.CO;2-M

Christe, Yves, 2006, “L'iconografia e il ruolo dell'esegesi”, en L'arte medievale nel contesto, зоo1300: funzioni, iconografia, tecniche, Paolo Piva ed., Milano, Jaca Book, 275-92.

Codina, Daniel; Bourgain, Pascale; Besseyre, Marianne, 20o9, "Lettre-sermon du moine Garsias de Cuxa à l'abbé Oliba”, Les Cahiers de Saint-Michel de Cuxa 40, 65-76.

Codina, Lluís; Pedraza-Jiménez, Rafael, 2OII, “Tesauros y ontologías en sistemas de información documental”, El Profesional de la Información 20-5, 555-63. http://dx.doi.org/IO.3I45/ epi.2OII.sep.IO

CSEL: Österreichische Akademie der Wissenschaften, ed., I866-, Corpus Christianorum Ecclesiasticorum Latinorum series, Salzburg, 96 vols.

Didi-Huberman, Georges, 2002, L'image survivante: Histoire de l'art et temps de fantômes selon 
Aby Warburg, Paris, Les Éditions de Minuit.

Didi-Huberman, Georges, 20I3, "Science avec patience", Images Re-vues, hors-série 4, http:// imagesrevues.revues.org/3024 (checked 29-O5-2014).

Duggan, Lawrence G., I989, "Was art really the book of the illiterate?”, Word \& Image, 5, 27-25I. http://dx.doi.org/IO.IO80/O2666286.Ig89.IO435406

Eddy, W. F.; Mocus, A., I994, "An interactive image index", en Proceedings of the Section on Statistical Graphics: Papers presented at the annual meeting of the American Statistical Association, Toronto, 1994 under the sponsorship of the Section on Statistical Graphics, Alexandria, VA, American Statistical Association, I-6.

Elsner, Jaś, 1995, Art and the Roman viewer: The transformation of art from the pagan world to Christianity, Cambridge, Cambridge University Press.

Elsner, Jaś, 20IO, “Art history as ekphrasis", Art History 33, IO-27. http://dx.doi.org/IO.IIII/ j.I $467-8365.2009 .00720 . \mathrm{X}$

Enser, Peter, 2008, "The evolution of visual information retrieval”, Journal of Information Science 34-4, 53I-46. http://dx.doi.org/IO.II77/OI6555I50809IоI3

Falque Rey, Emma, ed., I994, Historia compostelana, Madrid, Akal.

Fischer, J., I984, “Entitling”, Critical Inquiry II, 286-98. http://dx.doi.org/Io.Io86/448289

GAHOM [Groupe d'Anthropologie Historique de I’Occident Medieval], ı993, Thésaurus des images médiévales pour la constitution de bases de données iconographiques, Paris, Ecole des Hautes Etudes en sciences sociales.

Galí, Neus, I999, Poesía silenciosa, pintura que habla, Barcelona, El Acantilado.

García Avilés, Alejandro, 200o, "Imagen, texto, contexto: reflexiones sobre el método iconográfico en el umbral del siglo XXI”, Boletín del Museo del Prado I8-36, IOI-I8, http://dialnet.unirioja. es/servlet/articulo? codigo $=\mathrm{I} 255638$ (checked 29-O5-2OI4).

Garnier, François, I984, Thésaurus iconographique, système descriptif des représentations, Paris, Le Léopard d'Or.

Golbeck, J.; Koepfler, J.; Emmerling, B., 2OII, "An experimental study of social tagging behavior and image content", Journal of the American Society for Information Sciences and Technology 62 , I750-6o. http://dx.doi.org/IO.IOO2/asi.2I522

Goldhill, Simon, 2007, "What is ekphrasis for?", Classical Philology IO2-I (Special Issues on Ekphrasis, Shadi Bartsch, Jaś Elsner ed.), I-I9. http://dx.doi.org/IO.IO86/52II29

Gombrich, Ernst, 1984, Art and illusion: A study in the psychology of pictorial representation, London, Phaidon Press (ig6o).

Gombrich, E. H, 1992, Aby Warburg: una biografía intelectual, Madrid, Alianza Forma (1970).

González Marín, Carmen, I999, “Deconstrucción: ironía e ironistas”, en Historia de las ideas estéticas y de las teorías artísticas contemporáneas, vol. 2, Valeriano Bozal ed., Madrid, Visor, $405^{-2} 6$.

Guardia, Milagros, 20II, San Baudelio de Berlanga: una encrucïada, Barcelona, Memoria Artium.

Guardia, Milagros; Lorés, Immaculada; Mancho, Carles et al., 2OI4, "El projecte d’Ars Picta: la 
contextualització virtual de la pintura mural romànica catalana”, en Humanitats a la xarxa: món medieval / Humanities on the web: the medieval world, L. Soriano, H. Rovira, M. Coderch et al. ed., Bern, Peter Lang, 2I3-33.

Hagelstein, Maud, 2OII, "L'histoire des images selon Warburg: Mnémosyne et ses opérations de cadrage", en Cadre, seuil, limite: La question de la frontière dans la théorie de l'art, Thierry Lenain, Rudy Steinmetz ed., Bruxelles, La Lettre Volée, 25I-79.

Halliwell, Stephen, 2000, "Plato and painting", en Word and image in ancient Greece, N. Keith Rutter, Brian A. Sparkes ed., Edinburgh, Edinburgh University Press, 99-гі6.

Hare, Jonathon S.; Lewis, Paul H.; Enser, Peter G. B. et al., 2006, "Mind the gap: Another look at the problem of the semantic gap in image retrieval”, Multimedia content analysis, management and retrieval, San José 20o6, San José, CA, SPIE and IS\&T, http://eprints.soton.ac.uk/id/ eprint/26I887 (checked 29-O5-20I4). http://dx.doi.org/IO.III7/I2.647755

Harpring, Patricia, 2002, "The language of images: Enhancing access to images by applying metadata schemas and structured vocabularies", en An introduction to art image access: Issues, tools, standards, strategies, Murtha Baca ed., Los Angeles, Getty Research Institute, http:// tinyurl.com/harpring2OO2 (checked 29-O5-2OI4).

Hourihane, Colum, 2002, "It begins with the cataloguer: Subject access to images and the cataloguer's perspective”, en An introduction to art image access: Issues, tools, standards, strategies, Murtha Baca ed., Los Angeles, Getty Research Institute, http://tinyurl.com/ Hourihane2OO2 (checked 29-O5-2OI4).

Hourihane, Colum, 2005, s.v. "Iconography", en New dictionary of the history of ideas, vol. 3: Game theory to Lysenkoism, Detroit-Munich, Scribner-Thomson Gale, Io69-78.

Jörgensen, Corinne, 2007, "Image access, the semantic gap, and social tagging as a paradigm shift", Advances in Classification Research Online, North America I8, http://journals.lib.washington. edu/index.php/acro/article/view/I2868 (checked 29-O5-2OI4). http://dx.doi.org/IO.7I52/ $\underline{\text { acro.vI8iI.I2868 }}$

Junyent, Eduard, ed., 1992, Diplomatari i escrits literaris de l'abat ibisbe Oliba, Barcelona, Institut d'Estudis Catalans.

Kessler, Herbert L., I994a, "Pictures as scriptures in Fifth-Century churches”, en Studies in Pictorial Narrative, London, The Pindar Press, 357-79 (1985).

Kessler, Herbert L., I994b, "Diction in the 'Bibles of the Illiterate", en Studies in Pictorial Narrative, London, The Pindar Press, 33-40 (1989).

Kuhn, Thomas S., I986, La estructura de las revoluciones científicas, México, Fondo de Cultura Económica (I962).

Labrada, María Antonia, 1984, "La racionalidad en la creación artística”, Anuario Filosófico I7-I, 45-63, http://hdl.handle.net/IOI7I/2I84 (checked 29-O5-2OI4).

Lazaris, Stavros, I996, "Décrire les images médiévales”, Les Cahiers de la Méditerranée 53, I49-64.

Lee, Rensselaer W., 1982, Ut pictura poesis: la teoría humanística de la pintura, Madrid, Cátedra.

Lizcano Rejano, Susana M., 200o, Pictura et poesis: narración mítica, imagen y descripción iconográfica en las "Imagines" de Filóstrato el Viejo, Tesis doctoral, Madrid, Universidad Complutense, http://eprints.ucm.es/tesis/I9972000/H/3/H306300I.pdf (checked 29-05- 
20I4).

López Ferreiro, Antonio, I90o, Historia de la santa a. m. iglesia de Santiago de Compostela, Santiago, Seminario Conciliar Central.

Lorés, Immaculada, 2007, “La sculpture de Saint-Michel de Cuxa à l'époque de l'abbé Oliba”, Les Cahiers de Saint-Michel de Cuxa 38, I83-91.

Maguire, Henry, 1994, Art and eloquence in Byzantium, Princenton, Princeton University Press.

Mâle, Émile, I9IO, L'art religieux du XIIIe siècle en France: Étude sur l'iconographie du moyen âge et sur ses sources d'inspiration, Paris, A. Colin.

Mancho, Carles, 2012, "Un métier très contemporain: Les artistes du haut Moyen Âge”, Les Cahiers de Saint-Michel de Cuxa 43, 9-I4.

Markiewicz, Henryk; Gabara, Uliana, 1987, "Ut pictura poesis: History of the topos and the problem", New Literary History I8-3, 535-58. http://dx.doi.org/IO.2307/469057

Martín Torres, María Teresa, 2000, “Los museos de museos: utopías para el control de la memoria artística”, Imafronte I5, I23-44. http://revistas.um.es/imafronte/article/view/3768I (checked 29-O5-2OI4).

Martín Torres, María Teresa, 2002, Historia de la documentación museológica: la gestión de la memoria artística, Gijón, Trea.

Martín Torres, María Teresa, 2004, "Los visionarios de la gestión de la memoria artística”, Revista da Faculdade de Letras, Ciências e Técnicas do Património, I Série, 3, 27I-9I, http://ler.letras. up.pt/uploads/ficheiros/4094.pdf (checked 29-O5-2OI4).

Moralejo Álvarez, Serafín, 20O4a, “Ars sacra et sculpture monumentale: Le trésor et le chantier de Compostelle”, en Patrimonio artístico de Galicia y otros estudios, tomo I, Ángela Franco Mata ed., Santiago de Compostela, Xunta de Galicia, I6I-88 (ז980).

Moralejo, Serafín, 2004b, "The Codex Calixtinus as an art-historical source”, en Patrimonio artístico de Galicia y otros estudios, tomo II, Ángela Franco Mata ed., Santiago de Compostela, Xunta de Galicia, 223-35 (I992).

Moralejo, A.; Torres, C.; Feo, J., ed., 2004, Liber Sancti Iacobi: “Codex Calixtinus", libro V, Santiago de Compostela, Xerencia de Promoción do Camiño de Santiago.

Nightingale, Andrea Wilson, 2004, Spectacles of truth in classical Greek philosophy: Theoria in its cultural context, Cambridge, Cambridge Universtity Press.

Orriols, Anna, I996, "Les imatges preliminars dels Evangelis de Cuixà (Perpinyà, Bibl. Mun., ms. I)”, Locvs Amoenvs 2, 3I-46.

Ottaway, John, 1994, "Une application du CD photo aux peintures murales : L'exemple de SaintPlancard”, Mélanges de l'Ecole Française de Rome: Moyen-Age, Temps Modernes Io6-I, I89-209. http://dx.doi.org/IO.3406/mefr.I994.3360

Panofsky, Erwin, 1972, Studies in iconology: Humanistic themes in the art of the Renaissance, New York, Icon Editions-Westview Press (I939).

PG: Migne, Jacques-Paul, ed., I857-I866, Patrologia Graeca series, Paris, I6I vols.

PL: Migne, Jacques-Paul, ed., I84I-I855, Patrologia Latina series, Paris, 2I7 vols. 
Platt, Verity Jane, 20II, Facing the gods: Epiphany and representation in Graeco-Roman art, Cambridge, Cambridge University Press.

Ponsich, Pierre, 1993, "Les baldaquins d'Oliba, IO40", Les Cahiers de Saint-Michel de Cuxa 24, $2 \mathrm{I}-7$.

Puig i Cadafalch, Josep, 19o9, L'arquitectura romànica a Catalunya, vol 2: Del segle IX al XI, Barcelona, Institut d'Estudis Catalans, https://archive.org/details/larquitecturaromo2puiguoft (checked 29-O5-2OI4).

Rampley, Matthew, 2OI2, "Bildwissenschaft: Theories of the image in German-language scholarship", en Art History and Visual Studies in Europe: Transnational Discourses and National Frameworks, Matthew Rampley, Thierry Lenain, Hubert Locher et al. ed., Leiden, Brill, II9-34.

Rigaux, Dominique, 1994, "Prealp: Une banque de données pour les peintures alpines", Mélanges de l'Ecole Française de Rome: Moyen-Age, Temps modernes Io6-I, I53-70. http://dx.doi. org/IO.3406/mefr.1994.3357

Schmitt, Jean-Claude, I987, "L'Occident, Nicée II et les images du VIIIe au XIIIe siècle”, en Nicée II, 787-1987, douze siècles d'images religieuses: Actes du colloque international 'Nicée II' tenu au Collège de France, Paris 1986, F. Boespflung, N. Lossky ed., Paris, Cerf, 27 I-302.

Schmitt, Jean-Claude, I99I, "Le groupe de recherches sur les images médiévales”, Les Cahiers du Centre de Recherches Historiques 8, http://ccrh.revues.org/282O (checked 29-05-2OI4). http:// dx.doi.org/I0.4000/ccrh.2820

Schmitt, Jean-Claude, 2002, Le corps des images: Essais sur la culture visuelle au Moyen Age, Paris, Gallimard.

Shatford Layne, Sara, 2002, "Subject Access to Art Images", en An introduction to art image access: Issues, tools, standards, strategies, Murtha Baca ed., Los Angeles, Getty Research Institute, http://tinyurl.com/ShatfordLayne2OO2 (checked 29-05-2OI4).

Schoell-Glass, Charlotte, 200I, “'Serious issues': The last plates of Warburg's picture atlas Mnemosyne", en Art history as cultural history: Warburg's projects, R. Woodfield ed., Amsterdam, G+B Arts International, I83-208.

Sprung, Joacim, 2OI4, “[...] Another phrase that is not by Warburg...”, Aby Warburg Appreciation Society, O7-O3-20I4, http://tinyurl.com/mb2ej42 (checked I5-O8-2OI4).

Squire, Michael, 20I3, "Apparitions apparent: Ekphrasis and the parameters of vision in the Elder Philostratus’s Imagines", Helios 4O, I-2, 97-I4O. http://dx.doi.org/IO.I353/hel.2OI3.0OI3

Straten, Roelof Van, I986, "Panofsky and ICONCLASS", Artibus et Historiae 7-I3,I65-8I. http:// dx.doi.org/IO.2307/I483254

Svenonius, E., I994, "Access to non-book materials: The limits of subject indexing for visual and aural languages", Journal of the American Society of Information Science 45-8, 6oo-6. http:// dx.doi.org/IO.IOO2/(SICI)IO97-457I(Ig9409)45:8<600::AID-ASII5>3.0.CO;2-6

Tatarkiewicz, Władysław, 20OI, Historia de seis ideas: arte, belleza, forma, creatividad, mímesis, experiencia estética, Madrid, Tecnos (1987).

Turing, Alan, I950, "Computing machinery and intelligence”, Mind 59-236, 433-6o, http://mind. oxfordjournals.org/content/LIX/236/433 (checked 29-O5-2OI4). http://dx.doi.org/IO.IO93/ 
$\underline{\operatorname{mind} / \text { LIX.236.433 }}$

Voyer, Cécile, 2OIO, "Histoire de l'art et anthropologie ou la définition complexe d'un champ d'étude", L'Atelier du Centre de Recherches Historiques 6, http://acrh.revues.org/2057 (checked 29-05-20I4). http://dx.doi.org/IO.4000/acrh.2057

Wallraven, C.; Fleming, R.; Cunningham et al., 20o9, "Categorizing art: Comparing humans and computers”, Computers \& Graphics 33-4, 484-95. http://dx.doi.org/IO.IOI6/j. cag.2009.04.003 